Estudios Constitucionales, Año 12, No 1, 2014, pp. 105-161.

ISSN 07180195

Centro de Estudios Constitucionales de Chile Universidad de Talca

"El contexto, las técnicas y las consecuencias de la interpretación de la

Convención Americana de los Derechos Humanos"

Laurence Burgorgue-Larsen

\title{
EL CONTEXTO, LAS TÉCNICAS Y LAS CONSECUENCIAS DE LA INTERPRETACIÓN DE LA CONVENCIÓN AMERICANA DE LOS DERECHOS HUMANOS*
}

\author{
CONTEXT, TECHNIQUES AND EFFECTS OF THE INTERPRETATION \\ OF THE AMERICAN CONVENTION OF HUMAN RIGHTS
}

\author{
LAURENCE BURGORGUe-LARSEN** \\ Escuela de Derecho de la Sorbona-Universidad Paris I-Francia \\ laurence.burgorgue-larsen@univ-paris1.fr
}

\begin{abstract}
RESUMEN: Desde su creación, la Corte Interamericana siempre ha privilegiado la finalidad prohomine de la Convención Americana sobre Derechos Humanos. Para entender este fenómeno que le permite interpretar su texto de referencia de manera constructiva, este artículo examina el contexto en el cual ésta evoluciona. Por ende, después de haber introducido el tema (I Parte), los contextos jurídicos (el contenido de la Convención como tal), pero también político (el estado de la violencia institucionalizada en América Latina) y sociológico (la composición de la Corte) están descritos para entender las razones que pusieron, muy temprano, la Corte Interamericana a privilegiar de manera regular, cuando no sistemática, la interpretación más protectora de la Convención (II Parte). Una vez presentado el panorama general del contexto al cual la Corte está confrontada, son las técnicas de interpretación como tales las que están presentadas. Tienen como objeto interpretar los derechos protegidos de manera extensiva y tienen como consecuencias ampliar el ámbito de aplicación de la Convención Americana (III Parte). Son, al final del análisis, las consecuencias de tal metodología las que están analizadas tanto al nivel politico (la reacción de unos cuantos Estados) como al nivel jurídico e institucional (la recepción del control de convencionalidad en los Estados Parte y el aumento de las disidencias en el propio seno de la Corte) (IV Parte).

ABSTRACT: Since its inception, the Inter-American Court of Human Rights has always favoured the "pro-homine" purpose of the American Convention on Human Rights. To understand this phenomenon,
\end{abstract}

\footnotetext{
* Este artículo es la versión escrita y actualizada de una presentación efectuada en inglés en junio de 2013 en el marco de un seminario internacional organizado por el profesor R. K. Madsen en Copenhague ("Programa Icourts"). La versión definitiva ha sido presentada en español en Heidelberg en noviembre de 2013 en el Max Planck Institut durante un seminario relativo a los modos de legitimación de los tribunales internacionales organizado por M. Morales Antonazzi y A. Von Bogdandy. Agradezco a Rosmerlin Estupinan Silva por la muy buena traducción en español de este trabajo. Artículo recibido el 28 de diciembre de 2013 y aprobado el 7 de mayo de 2014.

** Catedrática de Derecho Público en la Escuela de la Sorbona (Paris I). Directora del GEDILAS (Grupo de Estudio del Derecho Internacional y Latino-Americano de la Sorbona). Vicepresidenta del Tribunal Constitucional de Andorra.
} 
which pushes the Inter-American Court to interpret its reference text in a constructive manner, it is necessary to examine the context in which it has evolved. Thus, after introducing the topic (Part I), Part II of this article describes the legal context (the content of the Convention) of the Court, as well as its political environment (the State of institutionalized violence in Latin America) and sociological nature (the composition of the Court). This will help us understand the reason why, early on, the Court chose to focus on a regular basis, if not systematically, on the most protective interpretation of the American Convention. The third Part looks at interpretation techniques as such. It shows that they are intended to interpret protective rights extensively and theses techniques have the effect of widening the scope of the Convention. Part IV examines the consequences of the evolutionary interpretation of the Convention, in legal, institutional and political terms.

PALABRAS CLAVE: Interpretación pro-homine, Técnicas de interpretación, Control de convencionalidad, Crisis politica, Opiniones disidentes.

KEY WORDS: Pro-homine interpretation, Techniques of interpretation, Conventionality control, Political upset, Pissent votes.

\section{INTRODUCCIÓN}

El tema de los métodos de interpretación de los tratados internacionales ha suscitado, estos últimos años, un interés renovado por parte de numerosos internacionalistas. Es en efecto revelador descubrir que el European Journal of International Law ${ }^{1}$, la Revue générale de droit international public ${ }^{2}$ y el German Law Journal ${ }^{3}$ consagraron, entre 2010 y 2011, números especiales a esta temática. Esta renovación en el análisis, de una cuestión sumamente clásica ${ }^{4}$, se explica de dos maneras. La primera explicación es de tipo mecánico. La multiplicación de jurisdicciones internacionales ha acarreado, con toda lógica, un interés doctrinal relativo a su funcionamiento y a su modo de producción jurisprudencial ${ }^{5}$. La segunda explicación se refiere a los métodos de interpretación en sí mismos. Las técnicas empleadas por ciertas jurisdicciones regionales derogan de manera clara

1 European Journal of International Law, "Symposium: The Interpretation of Treaties - A Re-examination", Issue Vol. 21, 2010, № 3.

2 Revue générale de droit international public, "Dossier: Les techniques interprétatives de la norme internationale", 2011, No 2.

3 German Law Journal, "Beyond dispute: International Judicial Institutions as Lawmakers", 2011, Issue number 5 .

${ }^{4}$ La codificación de las reglas relativas a la interpretación de los tratados fue garantizada por la célebre Convención de Viena de 1969, el "tratado de los tratados". La redacción del artículo 31 es importante en este sentido porque enumera todos los métodos de interpretación de los tratados, cuando el artículo 32 presenta los métodos "complementarios" de interpretación.

5 Societe Francaise de Droit International (2003), p. 545. 
el clasicismo interpretativo todavía predominante en el seno de la jurisdicción histórica y universal, la Corte Internacional de Justicia (CIJ). La primacía de las técnicas de interpretación históricas y exegéticas donde la voluntad de los Estados debe prevalecer in fine (CIJ) ha dado paso a una valorización de la interpretación teleológica (basada en el "objeto y fin" del tratado). Esta tendencia es un fenómeno de fondo. Tal fenómeno es sintomático de las jurisdicciones regionales de las organizaciones de integración ${ }^{6}$, pero igualmente $-\mathrm{y}$ sobre todo- de las jurisdicciones regionales para la protección de los derechos humanos. En el marco de los sistemas de integración, se busca hacer primar los objetivos económicos de los tratados básicos (es decir, el establecimiento de un mercado común o una moneda única); en el marco de los sistemas de garantía regional de derechos humanos, se persigue no pasar por alto la finalidad humanista de los Convenios de protección. Si el Tribunal Europeo de Derechos Humanos (TEDH) llama regularmente la atención debido a su audacia interpretativa ${ }^{7}$, la Corte Interamericana no se queda atrás. Desde su creación, siempre ha favorecido la finalidad pro-homine de la Convención Americana sobre Derechos Humanos.

Para comprender este fenómeno, que impulsa a la Corte Interamericana de Derechos Humanos (Corte IDH) ${ }^{8}$ y que consiste en interpretar su texto de referencia de una manera constructiva, es necesario examinar el contexto en el que ella evoluciona. Así, en una primera parte, el contexto legal (el contenido de la Convención), así como los contextos político (el estado de la violencia institucionalizada en América Latina) y sociológico (la composición de la Corte) serán descritos con el fin de comprender las razones que llevaron, desde muy temprano, a la Corte IDH a privilegiar de manera regular, cuando no sistemática, la interpretación más protectora de la Convención Americana (Sección II). Es en una segunda parte donde las técnicas de interpretación serán presentadas como tal. Vamos a ver que ellas están destinadas a interpretar los derechos protegidos de manera extensiva y que tienen como consecuencia ampliar el ámbito de aplicación de la Convención (Sección III). Vamos a terminar este análisis presentando las consecuencias de la interpretación evolutiva de la Convención, tanto en términos jurídicos e institucionales como políticos (Sección IV).

\footnotetext{
${ }^{6}$ El Tribunal de Justicia de la Unión Europea (TJUE), la Corte de Justicia de la Comunidad de Estados de África del Oeste (CEDEAO), la Corte de Justicia de la Comunidad Andina de Naciones (Corte CAN), la Corte de Justicia del Sistema de Integración Centroamericano (Corte SICA).

7 Burgorgue-Larsen, Laurence (2014), pp. 101-115; (2012 b), pp. 90-123; (2010), pp. 145-173.

8 En adelante, Corte IDH, Corte Interamericana, Corte de San José o Corte.
} 


\section{EL CONTEXTO INTERPRETATIVO}

La interpretación evolutiva de la Corte Interamericana se explica por la combinación de tres tipos de factores: el derecho (A), la política (B) y, en fin, la sociología de la Corte como institución judicial (C).

\section{A. El contexto jurídico}

Desde el comienzo de su actividad (primera opinión ${ }^{9}$ y primera sentencia ${ }^{10}$ ) hasta las últimas decisiones emitidas ${ }^{11}$, la Corte de San José ha sabido relacionar su enfoque interpretativo con las normas generales de interpretación de los tratados codificadas en los artículos 31 y 32 de la Convención de Viena ${ }^{12}$. Así ha integrado inmediatamente su enfoque en el juego clásico de normas establecidas por el derecho internacional en materia de interpretación. Ella ha, obviamente, destacado de inmediato la disposición propia a la Convención Americana que trata la cuestión de la interpretación: el célebre artículo 29, titulado "Normas de Interpretación". Esta disposición última, que no tiene equivalente en el seno del $\mathrm{TEDH}$, valoriza el principio pro-homine. Éste consiste en proveer una interpretación que pueda otorgar a los individuos una protección máxima, es decir, pronta a privilegiar la interpretación más favorable a los individuos. El artículo 29.b) ${ }^{13}$ es emblemático en este sentido. Fue cómodo para la Corte, a partir de ahí, privilegiar el método teleológico: expresamente mencionado en el artículo 31.1 in fine de la Convención de Viena, está además inducido por la lógica del artículo 29 de la propia Convención Americana. Si toda la jurisprudencia de la Corte Interamericana está impregnada por este enfoque, esto no significa en absoluto que haya desestimado de forma sistemática y definitiva los otros métodos de interpretación (textual, histórico, sistemático). Éstos surgen con fuerza especialmente

9 Corte IDH, "Otros tratados". Objeto de la función consultiva de la Corte (artículo 64 de la Convención Americana), AC-1/82 Opinión Consultiva de 24 de septiembre de 1982, Serie A No 1.

10 Corte IDH, Excepciones Preliminares, 26 de junio 1987, Velásquez Rodríguez vs. Honduras, Serie C No 1; Corte IDH, Fondo, 29 de julio de 1988, Velásquez Rodríguez vs. Honduras, Serie C No 4.

11 En el momento en que estas líneas terminan de escribirse (finales de noviembre de 2013), son accesibles las sentencias de fondo de agosto 2013.

12 Gros Espiell, Héctor (1994), pp. 223-244.

13 Se lee así: "Ninguna disposición de la presente Convención puede ser interpretada en el sentido de: [.../...] b) limitar el goce y el ejercicio de cualquier derecho o libertad que pueda estar reconocido de acuerdo con las leyes de cualquiera de los Estados Parte o de acuerdo con otra convención en que sea parte uno de dichos Estados". 
en los "casos difíciles" (hard cases), por ejemplo, en lo que concierne al carácter justiciable de los derechos económicos y sociales (artículo 26) ${ }^{14}$ o en lo que toca a la significación y el alcance del derecho a la vida (artículo 4) ${ }^{15}$.

A continuación del artículo 29 de la Convención -que es el principal eslabón técnico que permitió a la Corte marcar inmediatamente su preferencia por la protección máxima de los derechos- conviene igualmente mencionar el alcance de competencia ratione materiae de la Corte. Bajo ciertas condiciones puede aplicar $^{16}$ a los hechos materia del proceso mencionados fuentes diferentes de la propia Convención Americana stricto sensu ${ }^{17}$. Podría pensarse que se trata de una manifestación clásica de lo que plantea el artículo 31.3 (y más particularmente el inciso c)) de la Convención de Viena ${ }^{18}$. En realidad, la práctica contenciosa demuestra que la Corte IDH sobrepasa su tenor. Si los conceptos provenientes de estos diferentes tipos de instrumentos interamericanos (concepto de tortura, violencia, desaparición forzada, asociación sindical) son en efecto aplicados en los casos en que los Estados concernidos han ratificado las Convenciones, éstos son también utilizados con fines de interpretación en otros casos.

Por tanto, un fenómeno de migración (interconvencional) se ha puesto en marcha privilegiando, una y otra vez, las interpretaciones más favorables a los derechos de las personas. De repente, la interpretación más protectora termina por imponerse al conjunto de los Estados Parte en la Convención Americana, incluidos los que no han ratificado estos convenios especializados.

Si se añade a estos diferentes elementos de carácter técnico la filosofía iusnaturalista que impregna tanto la Declaración Americana de los Derechos y

\footnotetext{
14 Corte IDH, 1 de julio de 2009, Excepciones Preliminares, Fondo y Reparaciones, Acevedo Buendía y otros (Cesantes y jubilados de la Contraloría) vs. Perú, Serie C No 198, \$\$101 y ss.

15 Corte IDH, 28 de noviembre de 2012, Excepciones Preliminares, Fondo y Reparaciones, Artavia Murillo y otros (Fecundación in vitro) vs. Costa Rica, Serie C No 257, \$\$171 y ss.

16 A partir del momento en que el Estado demandado haya ratificado la Convención que está "en juego" en el proceso interamericano.

17 Se trata de la Convención Interamericana contra la Tortura y Otros Tratos o Penas Crueles, Inhumanos o Degradantes, de 8 de diciembre de 1985, y de dos Convenios adoptados el mismo día, 9 de junio de 1994 en Belém do Pará (Brasil): la Convención Interamericana sobre Desapariciones Forzadas y la Convención Interamericana para Prevenir, Sancionar y Erradicar la Violencia contra la Mujer. A este tríptico convencional, hace falta agregar el Protocolo de San Salvador sobre Derechos Económicos y Sociales, del 17 de noviembre de 1988.

18 El artículo 31.3 afirma: "Juntamente con el contexto, habrá de tenerse en cuenta: [.../...] c) Toda forma pertinente de derecho internacional aplicable en las relaciones entre las partes".
} 
Deberes del Hombre ${ }^{19}$ (1948), como la Convención Americana ${ }^{20}$ (1969), todos los ingredientes están reunidos para que la Corte Interamericana privilegie un enfoque interpretativo teleológico y evolutivo.

\section{B. El contexto politico}

La violencia es inherente a la historia del continente latinoamericano: guerrillas, contraguerrillas, guerras civiles, terrorismo de Estado ${ }^{21}$ son, en efecto, el estigma del pasado ${ }^{22}$ de numerosos países de América Latina. A estos elementos complejos y violentos, falta agregar los horrores generados por la política de los Estados Unidos de América en lo que ellos han considerado por mucho tiempo como su "patio trasero". Aunque la doctrina de la no intervención promovida por Franklin D. Roosevelt logró imponerse durante algún tiempo a partir de 1933, la llegada al poder en varios países de América Central y del Sur de regímenes socialistas o comunistas acabó con este enfoque después de 1950.

La doctrina de la seguridad nacional se instaló y se extendió en el continente con el apoyo de los Estados Unidos, ansiosos de contener el expansionismo "rojo". Este contexto político violento no pudo ser ignorado por los órganos del sistema interamericano, como tampoco subestimado, ni mucho menos descartado. La Comisión Interamericana de Derechos Humanos ${ }^{23}$ fue la primera desde 1959 (fecha de su creación) en verse confrontada a esto. Ella hizo frente como pudo a atrocidades de todo tipo perpetradas, a menudo, como resultado de golpes de Estado. Tuvo que ser "activista", excediendo con frecuencia el silencio de su estatuto y/o de las normas de procedimiento, para estar en capacidad de enfrentar y luchar eficazmente contra las violaciones masivas de los derechos humanos. Es a través de

19 Preámbulo, párrafo 2: "Que, en repetidas ocasiones, los Estados americanos han reconocido que los derechos esenciales del hombre no nacen del hecho de ser nacional de determinado Estado sino que tienen como fundamento los atributos de la persona humana". Para un estudio magnífico acerca de los lazos entre América latina y los derechos humanos, ver CArozZa G., Paolo (2003), pp. 282-313.

20 Preámbulo, párrafo $2^{\circ}$ : "Reconociendo que los derechos esenciales del hombre no nacen del hecho de ser nacional de determinado Estado, sino que tienen como fundamento los atributos de la persona humana, razón por la cual justifican una protección internacional, de naturaleza convencional coadyuvante o complementaria de la que ofrece el derecho interno de los Estados americanos".

21 La Operación Cóndor fue el funesto emblema.

22 A veces, incluso en el presente, lamentablemente. Si se piensa en el "conflicto colombiano", que es uno de los más largos de la historia de las guerrillas latinoamericanas, ver los problemas que eso genera en términos de justicia transicional en Uprimmy, Rodrigo; SAFFON, M.P. (2008), pp. 165-195.

23 En adelante, "la Comisión" o la "Comisión Interamericana". 
la publicación y la publicidad correspondiente con que ella otorgó sus informes realizados sobre la situación de los derechos humanos en los Estados miembros (a raíz de sus visitas in loco), que reafirmó su autoridad y su legitimidad ${ }^{24}$.

Es de notoriedad pública que la visita a Argentina en 1979, por parte de miembros de la Comisión presidida en la época por Tom J. Farer -seguida de la publicación de su informe en 1980-, fue la más exitosa. Por un lado, el mundo entero, y la Organización de las Naciones Unidas a la cabeza, tomó nota de la práctica de las desapariciones forzadas perpetradas por la dictadura del general Videla; por otro lado, éstas disminuyeron significativamente después de memorable visita in loco. Una vez creada la Corte Interamericana ${ }^{25}-$ y en capacidad de trabajar ${ }^{26}$-, ella también se vio confrontada a los estigmas de la violencia institucionalizada que asolaba el continente. En el marco de su función consultiva, la Corte tuvo que detenerse, en dos de sus opiniones ${ }^{27}$, en el estudio de las grandes líneas del régimen jurídico de las excepciones a los derechos garantizados. ¿Cómo no entender que haya optado por una interpretación restrictiva de las posibilidades de suspender ciertos derechos -usando las herramientas del artículo 29 de la Convención- cuando sabemos que los gobiernos latinoamericanos no han cesado de instrumentalizar la noción de "medidas de excepción"? Para convencerse es suficiente con referirse al análisis de uno de los expresidentes de la Corte, el uruguayo Héctor Gros Espiell:

"Las medidas de excepción -que no deben de ninguna manera conducir ni a la suspensión de la constitución ni a la eliminación del Estado de Derecho- (... / ...) han servido en América Latina, en muchas ocasiones, para abolir la constitución, derrocando los gobiernos legítimos para usurpar el poder. Los estados de excepción se han utilizado a menudo para disimular los golpes de Estado o como cortina de humo para ocultar el comienzo de regímenes tiránicos"28.

\footnotetext{
24 Puede leerse con interés acerca de este período: GonZALEZ, Felipe (2009), pp. 103-125; Goldman, Robert K. (2009), pp. 856-887.

25 Con la firma en San José de Costa Rica de la Convención Americana de los Derechos Humanos, conocida igualmente bajo el nombre de "Pacto de San José", el 22 de noviembre de 1969.

26 A partir de 1978 (18 de julio), fecha de entrada en vigor de la Convención Americana.

27 Corte IDH, 30 de enero de 1987, El habeas corpus bajo suspensión de garantías, Serie A No 8 (demanda formulada por la Comisión); Corte IDH, 6 de octubre de 1987, Las garantías judiciales en estados de emergencia, Serie A No 9 (demanda formulada por Uruguay).

28 Gros Espiell, Héctor (1989), p. 296. Para un análisis de la acción pionera de la Comisión Interamericana en Situaciones de Excepción: Fitzpatrick, J. (2004), pp. 371-394. Para un análisis de la guerra en la
} 
Así, al interrogarse sobre si durante este tipo de períodos de excepción los Estados podían suspender las garantías de orden judicial29, la Corte respondió en sentido negativo ${ }^{30}$. Tal enfoque "realista" ha caracterizado igualmente, en toda lógica, la actividad de la Corte en el contencioso. Su jurisprudencia "fundadora" se manifestó, en efecto, en los tres primeros "casos hondureños" relativos al fenómeno macabro de las desapariciones forzadas. El primero de ellos -el caso Velásquez Rodríguez- es emblemático de un período político marcado por el autoritarismo dictatorial al punto de hallarse irremediablemente vinculado a la obra histórica de la Corte de San José ${ }^{1}$. ¿Qué hubiera sido de la eficacia del sistema interamericano de garantía de derechos si la Corte no hubiera descartado la regla clásica de derecho penal según la cual no hay crimen sin cuerpo? ¿Qué hubiera sido de su capacidad para hacer frente a lo que constituyó (y constituye todavía) uno de los aspectos más importantes de la realidad latinoamericana si no hubiera deducido la naturaleza continua de tal crimen? ¿Qué hubiera sido de su legitimidad si no hubiera utilizado la combinación de fundamentos jurídicos para nombrar e identificar no un nuevo derecho (v. infra), pero un nuevo crimen ${ }^{32}$ ? Preguntarse esto es evidentemente responderse. En un contexto como aquel, era lógico que la Corte decidiera luchar, sin desfallecer, contra la impunidad. Es posible de seguro decir que hoy en día el círculo se ha cerrado: después de haber deconstruido, para sancionarlo, el fenómeno de las desapariciones forzadas, su política jurisprudencial ha consistido en declarar inconvencionales per se las leyes de amnistía, incluidas aquellas que han sido adoptadas por la vía del referéndum ${ }^{33}$. Haciendo esto, ella

jurisprudencia de la Corte IDH, podemos remitirnos a Burgorgue-LarSen, Laurence; Úbeda De Torres, Amaya (2011 b), pp. 148-174.

29 Se trata tanto de garantías ofrecidas por el habeas corpus (artículo 7.6 de la Convención), como de otras más amplias referidas grosso modo al debido proceso y el recurso efectivo (artículos 8.1 y 25.1 de la Convención).

30 La Corte confirmaría más tarde este enfoque a través del contencioso: Corte IDH, 16 de agosto de 2000, Fondo, Durand y Ugarte vs. Perú, Serie C No 68; Corte IDH, 18 de agosto de 2000, Fondo, Cantoral Benavides vs. Perú, Serie C No 69.

31 Grossmann, Claudio (2007), pp. 77-113.

32 El crimen de desaparición forzada pudo ser estudiado por la Corte porque ella estimó que se trataba de un crimen complejo derivado de la combinación de la violación de una serie de fundamentos jurídicos: el artículo 3 (derecho a la personalidad jurídica), 4 (derecho a la vida), 5 (derecho a la integridad) y 7 (derecho a la libertad personal).

33 Corte IDH, 14 de marzo de 2001, Fondo, Barrios Altos vs. Perú, Serie C No 75; Corte IDH, 3 de septiembre de 2001, Interpretación, Barrios Altos vs. Perú, Serie C No 83; Corte IDH, 29 de noviembre de 2006, Fondo y Reparaciones, La Cantuta vs. Perú, Serie C No 162; Corte IDH, 26 de septiembre de 2006, Fondo y Reparaciones, Almonacid Arellano y otros vs. Chile, Serie C No 154; Corte IDH, 24 de 
contribuye a erradicar del paisaje de numerosas democracias latinoamericanas la figura del "olvido" - que es la marca de las leyes de amnistía- para privilegiar la de justicia, que permite la apertura de procesos nacionales con fines de persecución de autores de numerosos crímenes cometidos durante los períodos más sombríos de numerosos países latinoamericanos.

\section{El contexto sociológico}

Descubrir los miembros que han sido o son actualmente jueces ante la Corte Interamericana es un medio subsidiario para comprender la valorización de las técnicas de interpretación que favorecen la protección más amplia de los derechos de la persona humana. Después de la influencia de los elementos estrictamente técnicos (véase el apartado I.A), la posición doctrinal de los jueces es otro factor explicativo de la interpretación pro persona. Un juez formado de manera "clásica" en derecho internacional público -donde la soberanía de los Estados es el cursor del análisis positivista del derecho internacional- no tendrá la misma manera de ver las cosas que un abogado sensible a las tesis del derecho natural y/o que ha estado activo (y posiblemente lo sigue estando) en las actividades de protección y promoción de los derechos humanos en calidad de abogado comprometido -ciertos dirían "activista"-. En consecuencia, las opciones "doctrinales" pueden tener una importancia decisiva cuando se recuerda que la Corte sólo se compone de siete magistrados elegidos para un mandato de seis años, renovable una sola $v^{3 e}{ }^{34}$, y que ellos están apoyados por una cantidad de jóvenes "abogados", todos

noviembre de 2010, Excepciones Preliminares, Fondo y Reparaciones, Gomes Lund y otros (Guerrilha do Araguaia) vs. Brasil, Serie C No 219; Corte IDH, 24 de febrero de 2011, Fondo y Reparaciones, Gelman vs. Uruguay, Serie C No 221. Véase, entre la abundante literatura: Binder, Cristina (2011), pp. 1204-1240; Burgorgue-Larsen, Laurence (2012 a), pp. 17-56; Martin, Claudia (2007), pp. 777-792; Parra Vera, Óscar (2012), pp. 5-51.

34 Los jueces deben ser nacionales de un Miembro de la Organización de Estados Americanos (Organization of American States, OEA). Son elegidos por la Asamblea General de la OEA sobre la base de una lista de tres personas presentadas por los Estados. De acuerdo con el artículo 53.1 de la Convención Americana, el voto es secreto y se debe obtener la mayoría absoluta de los miembros de la OEA. La última elección tuvo lugar en Cochabamba, Bolivia (5 de junio de 2012) durante la sesión de la XLII Asamblea General. En ella se eligió a tres nuevos jueces: el brasileño Roberto de Figueiredo Caldas, el colombiano Humberto Antonio Sierra Porto y el mexicano Eduardo Ferrer Mac-Gregor Poisot. Ellos entraron en funciones el 1 de enero de 2013 y se unen al chileno Eduardo Vio Grossi, al peruano Diego García Sayán, al costarricense Manuel E. Ventura Robles y al uruguayo Alberto Pérez Pérez. En la actualidad no hay mujeres en el seno de la Corte Interamericana, lo que es, realmente, inadmisible. 
ellos dedicados a la causa de los derechos humanos ${ }^{35}$. Después de una rápida mirada general a la formación recibida por los jueces (académicos o profesionales) y su especialidad (derecho internacional y/u otras disciplinas) ${ }^{36}$, voy a presentar la mayor influencia que algunos han podido tener en el curso de la jurisprudencia.

La Corte de San José ha estado integrada por grandes abogados de derecho internacional público, algunos de los cuales también han continuado su carrera internacional ${ }^{37}$. Así, la presencia del estadounidense Thomas Buergenthal (19791991) ${ }^{38}$, del venezolano Pedro Nikken (1979-1981) o del costarricense Rodolfo E. Piza Escalante (1970-1989) marcó indudablemente los primeros pasos de la Corte. Lo mismo ha ocurrido a lo largo de sus 35 años de funcionamiento, donde otros grandes nombres del derecho internacional han hecho presencia, todos eminentes académicos reconocidos internacionalmente por sus escritos: el argentino Julio A. Barberis (1990-1991), la chilena Cecilia Medina Quiroga (2004-2009), el colombiano Rafael Nieto Navia (1983-1994), el brasileño A. Cançado Trindade (1994-2006), el mexicano Héctor Fix-Zamudio (1985-1997) o el uruguayo Héctor Gros Espiell. Su reputación académica los ha llevado a menudo, igualmente, a actuar como asesores legales de su Estado o a integrar en calidad de expertos, en particular, las organizaciones independientes del cuerpo de las Naciones Unidas ${ }^{39}$. La Corte no ha sido integrada exclusivamente, sin embargo, por universitarios especializados en derecho internacional. Así pues,

35 Las modalidades de trabajo interno en el seno de la Corte IDH no se pueden pasar por alto. Los "abogados" provienen de todos los países latinoamericanos y son ellos quienes trabajan en permanencia para la Corte (mientras que los jueces sólo están presentes durante el período de sesiones). Los "abogados" de alguna manera son "las hormigas obreras" de la Corte de San José. En el trabajo de investigación en derecho comparado, en la asistencia en redacción, en las soluciones propuestas, su función es realmente vital. Ellos podrían ser comparados a los miembros de la Secretaría del TEDH, de la que se sabe que ejerce un trabajo mayor de preparación de las decisiones de justicia. Relativamente jóvenes (la edad promedio es de alrededor de 30 años), por lo general todos están marcados por el deseo de hacer avanzar la "causa" de los derechos humanos.

36 El conjunto de las informaciones recogidas derivan del descubrimiento de los CV de los diferentes jueces, disponibles on line en el sitio de la Corte y/o en el sitio de su Universidad de origen.

37 Thomas Buergenthal (estadounidense) y A. Cançado Trindade (brasileño) ejercieron, ulteriormente, como jueces ante la CIJ, mientras que Rafael Nieto Navia (colombiano) formó parte de la Sala de Apelaciones del Tribunal Penal para ex Yugoslavia (TPIY). Pedro Nikken, por su parte, fue elegido en 2011 como presidente de la "Comisión Internacional de Juristas", la más grande ONG de defensa de los derechos humanos creada en 1952 (www.icj.org).

38 Las cifras entre paréntesis corresponden al período de mandato de los jueces. Este no es siempre igual a 6 años o 12 años en caso de renovación, porque es necesario contar en algunas ocasiones con dimisiones durante el mandato.

39 Así, por ejemplo, Antônio Cançado Trindade, Cecilia Medina Quiroga o Eduardo Vio Grossi. 
Sergio García Ramírez (1998-2007) es un gran especialista mexicano en derecho penal con una producción científica prolífica ${ }^{40}$. En efecto, además de ser investigador en esta área del derecho en el seno del prestigioso e influyente Instituto de Investigación Jurídica (IIJ) de la Universidad Nacional Autónoma de México (UNAM), sus escritos lo han llevado a abordar temas de derecho internacional penal, derecho constitucional y derecho internacional de los derechos humanos ${ }^{41}$. En cuanto a la dominicana Rhadys Iris Abreu Blondet, es doctora en criminología. Los últimos jueces elegidos ante la Corte ${ }^{42}$, el mexicano Eduardo Ferrer Mac Gregor Poisot y el colombiano Humberto Antonio Sierra Porto vienen, a su vez, del mundo del derecho constitucional: el primero, enseña en la UNAM $y$, al igual que su predecesor, está vinculado con el Instituto de Investigación Jurídica (IIJ-Institut de Recherche Juridique), donde dirige múltiples revistas y colecciones de derecho constitucional ${ }^{43}$; el segundo ha tenido, por su parte, después de la obtención de un doctorado en derecho constitucional en España (Universidad Autónoma de Madrid) una carrera como profesor de derecho constitucional de la Universidad Externado, por un lado, y, por el otro, a partir de 2004, una carrera como magistrado constitucional en el seno de la 'prestigiosa' 44 Corte Constitucional de Colombia.

Otro elemento interesante en la formación de los jueces es el hecho de que no han sido sistemáticamente académicos. Este fue el caso del juez y antiguo presidente mexicano de la Corte, Sergio García Ramírez quien dispone de una notoriedad fuera del común en su país por haber ejercido -además de funciones

\footnotetext{
40 Sus publicaciones son innumerables, sólo citaremos la última, a la fecha, en derecho penal que se produjo bajo su coordinación, en conjunto con O. Islas De González Mariscal y J. Ojeda Velásquez (2013).

41 Para un estudio a la frontera del derecho internacional de los derechos humanos y del derecho constitucional: García Ramírez, Sergio; Morales Sánchez, Julieta (2012), p. 318.

42 Elegidos durante la reunión de la Asamblea General de la OEA en Cochabamba (Bolivia), entraron en función el 1 de enero de 2013.

43 Este en particular especializado en derecho procesal constitucional, como lo demuestra la obra reciente bajo su dirección: Ferrer Mac-Gregor, Eduardo (dir.) (2013).

44 El calificativo de 'prestigiosa' Corte Constitucional no es inmerecido. En efecto, la Corte colombiana goza de una de las mejores reputaciones en el continente latinoamericano. Aparte del hecho de que está compuesta por magistrados altamente calificados, su jurisprudencia es particularmente inventiva y sutil. Puede decirse, sin temor a equivocarse, que su jurisprudencia es, junto con la jurisprudencia de la Corte Suprema de Justicia de la Nación de México y Argentina, una de las más estudiadas y analizadas por los juristas del continente. La jurisprudencia de los últimos meses sin embargo revela, según ciertos autores, algunas regresiones. V. BARBoza Delgado, F.: "La sostenibilidad fiscal: desafío al Estado social de Derecho en Colombia”, en Revista de Derecho Público de la Universidad de los Andes, 2014.
} 
académicas- importantes funciones judiciales (fue Procurador General de la República ${ }^{45}$ y miembro del Instituto Federal Electoral ${ }^{46}$ ) y políticas (fue Secretario de Estado). Este es igualmente el caso del juez y presidente de la Corte, el peruano Diego García Sayán fue ministro -de Justicia y Asuntos Exteriores- de los gobiernos de transición democrática que siguieron a la dictadura de Alberto Fujimori ${ }^{47}$. Se trata, por lo tanto, de un hombre que ha ejercido altas funciones políticas en su país y tal ejercicio no deja de tener consecuencias en el comportamiento "diplomático" de su presidencia. En efecto, él está particularmente presente en diversas escenas mediáticas nacionales, saltando a la palestra para explicar (a menudo para defender) ciertas decisiones de la Corte Interamericana. Además, es de observar que algunos jueces son abogados en ejercicio. De las cuatro mujeres que han servido en la Corte desde sus inicios hasta la actualidad ${ }^{48}$, la jueza proveniente de Kingston -Margaret May Macaulay- tuvo una prestigiosa carrera como abogada (attorney at law) en Jamaica y en Gambia ante la Corte Suprema de Banjul. El recorrido profesional del juez brasileño en el cargo desde el 1 de enero de 2013 -Roberto de Figueiredo Caldas ${ }^{49}$ - es igualmente el de un abogado especializado en derecho laboral, que está a la cabeza de una de las más grandes

45 Se trata de un puesto clave en la estructura del estado de derecho mexicano que puede, en líneas generales, ser comparado al Ministerio Público. Él estuvo, por consiguiente, a la cabeza.

46 Se trata del órgano federal de control de las elecciones. Sus miembros son designados por la Cámara de Diputados.

47 Su mandato terminó el 31 de diciembre de 2013. La elección del 28 de noviembre de 2013 permitió al colombiano Humberto Sierra Porto ser elegido Presidente de la Corte para el período 2014-2015.

48 La chilena Cecilia Medina Quiroga (2004-2009), la costarricense Sonia Picado Sotela (1988-1994), la dominicana Rhadys Iris Abreu Blondet (2007-2012) y la jamaiquina Margaret May Macaulay (20072012). J. Mo Pasqualucci ha presentado la muy interesante trayectoria personal como profesional de la jueza costarricense, ver PASQUALUCCI, J. Mo (1995), pp. 794-806.

49 Antes de su elección, y de la misma manera que E. Ferrer Mac-Gregor -que había sido nombrado juez ad hoc en el caso histórico de Cabrera y Montiel Flores (Corte IDH, Excepciones Preliminares, Fondo, Reparaciones, 26 de noviembre de 2010, Cabrera García y Montiel Flores vs. México, Serie C No 220, ver tabla adjunta)-, el brasileño Figueiredo Caldas fue nombrado juez ad hoc en el caso Gomes Lund y otros (Corte IDH, Excepciones Preliminares, Fondo, Reparaciones, 24 de noviembre de 2010, Gomes Lund y otros (Guerrilha do Araguaia) vs. Brasil, Serie C No 219. En esta ocasión, Figueiredo Caldas emitió un voto concurrente, poniendo de relieve la importancia de la jurisprudencia interamericana en la lucha contra la impunidad. De esta manera, legitimó la solución adoptada por la Corte Interamericana que condenó a Brasil por haber adoptado y, además, mantenido en vigor la ley de amnistía. A la ocasión, la jurisprudencia del Tribunal Federal Supremo fue especialmente criticada por no haber ejercido el "control de convencionalidad" en contra de esta ley y, en consecuencia, por haberla declarado conforme a la Constitución (v. supra). Es interesante observar que este voto concurrente no le impidió ser presentado por su país para poder postularse para el cargo de juez de la Corte Interamericana. 
oficinas de abogados "laboralistas" del país; esta función lo ha llevado, de hecho, a presentar numerosos casos ante la Comisión Interamericana ${ }^{50}$.

Conocer la formación y la especialidad de los jueces de la Corte de San José provee indicios necesarios pero difícilmente suficientes para determinar si, in fine, son sensibles a las teorías clásicas del derecho internacional (donde la voluntad del Estado sigue siendo determinante) o si, a la inversa, la máxima protección de los derechos es más bien el cursor final de todo su análisis del derecho internacional de los derechos humanos. El descubrimiento de sus escritos y/o actividades (pasadas o presentes) permite afinar el análisis. Así, se puede tener una idea de la visión del derecho internacional defendida por Diego García Sayán cuando conocemos que hoy en día, junto a la oficina de juez de la Corte Interamericana, es también director general de la Comisión Andina de Juristas, una importante ONG regional de defensa de los derechos humanos. La misma reflexión puede hacerse extensiva cuando se conoce la historia personal y académica de la jueza chilena Cecilia Medina Quiroga. Asilada en Holanda durante numerosos años, cuando debió huir del régimen del terror del general Pinochet, ella defendió en la Universidad de Utrecht una tesis doctoral reconocida: The Battle of Human Rights, Gross Systematic violations and the Inter-American System ${ }^{51}$. De regreso a su país natal una vez restaurada la democracia, se convirtió en profesora de la Universidad de Chile, creó el Centro de Derechos Humanos y un Anuario de los Derechos Humanos y continuó publicando obras dedicadas específicamente al sistema interamericano de derechos humanos. Su libro publicado en 2005 -Convención Americana: Vida, Integridad personal, libertad personal, debido proceso $y$ recurso judicial ha sido particularmente reconocido ${ }^{52}$.

50 Esta breve reseña muestra una cosa: la gran variedad de perfiles de los jueces (académicos, políticos, abogados) y de su especialidad jurídica (derecho internacional, constitucional, penal, laboral). En este contexto, debe entenderse la retórica de algunas de las condiciones que deben cumplir los candidatos para ser nombrados jueces ante la Corte Interamericana, según lo establece el artículo 52 de la Convención Americana y el artículo 4 del Estatuto de la Corte. En efecto, los jueces deben ser: a) nacionales de un Estado miembro de la OEA, b) juristas, c) disponer de la "más alta autoridad moral", d) de una "reconocida competencia en materia de derechos humanos" y e) reunir "las condiciones requeridas para el ejercicio de las más elevadas funciones judiciales conforme a la ley del país del cual sean nacionales o del Estado que los proponga como candidatos". Podemos notar que si el punto c) es una condición clásica particularmente difícil de evaluar (al igual que disposiciones similares en otros tratados y estatutos internacionales), el punto d) está lejos de ser satisfecho en la práctica, pues algunos de los jueces que han sesionado en la Corte nunca tuvieron, antes de su nombramiento, "contacto" con el universo de la protección de los derechos humanos. Para un análisis crítico sobre el conjunto de estas condiciones: Ruiz-Chiriboga, Oswaldo (2012), pp. 111-135.

51 Medina Quiroga, Cecilia (1988), 363 pp.

52 Medina Quiroga, Cecilia (2005), 428 pp. 
La figura de Antônio A. Cançado Trindade 53 tampoco puede ser pasada por alto. Sus convicciones teóricas y filosóficas sobre la naturaleza y la finalidad del derecho internacional -que salieron a la luz tempranamente en el curso de su monumental tesis ${ }^{54}$ doctoral defendida en la Universidad de Cambridge en 197755 - han irrigado totalmente sus funciones de juez. Se trata ante todo de un intelectual que no ha dejado de poner presente, deberíamos decir de abogar, de defender, una visión humanista del derecho internacional. En este contexto de crítica radical al positivismo voluntarista, Antônio A. Cançado Trindade no tiene ningún tipo de dificultad en reconocer, asumir, mejor es, reivindicar, su compromiso iusnaturalista.

En el marco de esta breve reseña, forzosamente limitada ${ }^{56}$, es igualmente importante presentar otros tipos de carreras, como las de los jueces chileno (Eduardo Vio Grossi) y uruguayo (Alberto Pérez Pérez), quienes en 2010 reemplazaron a Cecilia Medina Quiroga y Sergio García Ramírez. El actual juez chileno fue formado en Francia, donde se doctoró en derecho público en 1976 en la Universidad de Grenoble. De regreso en Chile, ejerció numerosas funciones profesionales, que van desde el litigo nacional, pasando por la integración de comités expertos chilenos en materia de arbitraje o del derecho del mar $^{57}$, hasta su ejercicio como profesor de derecho internacional público en varias universidades del país, así como en el seno de la Academia Diplomática Chilena adjunta al Ministerio de Relaciones Exteriores. Ninguna especialización en derecho de los derechos humanos forma parte de su carrera; puede subrayarse incluso que ejerció en lados opuestos pues, como abogado, fue gerente general de la Asociación Chilena de Gas Licuado (GLP Chile). En cuanto a la carrera del uruguayo Alberto Pérez Pérez, está mar-

53 Para un análisis en mayor profundidad de su pensamiento y de su inserción en la doctrina latinoamericana del derecho internacional, remitimos a BURGORGUe-LARSEN, Laurence (2011), pp. 5-43.

54 Monumental es la palabra; con nada menos que 1728 páginas. Fue honrada con el Yorke Prize. Estuvo consagrada a un tema que llegará al apogeo en sus actividades como académico y como juez, es decir, la regla del agotamiento de los recursos internos. Fue publicada (en una versión reducida) en 1983 bajo el título The Application of the Rule of Exhaustion of Local Remedies in International Law, CANÇADO TRINDADE, Antônio (1983).

55 Su curso en la Academia de La Haya, dispensado en 2005, fue enteramente actualizado y reeditado. En él, se encarna perfectamente todo su enfoque epistemológico del derecho internacional: CANÇADO TRINDADE, Antônio (2010).

56 No puedo aquí, limitada por el espacio de este simple artículo, profundizar la carrera de todos los jueces. Estos son, por lo tanto, sólo algunos ejemplos presentados y escogidos de manera discrecional.

57 Está inscrito, desde 1988, en la lista de “conciliadores" de la Convención de Naciones Unidas sobre el derecho del mar. 
cada por una doble formación en derecho constitucional e internacional, seguida entre Uruguay, donde obtuvo su doctorado en 1960 y los Estados Unidos, donde continuó su formación entre las Universidades de Dallas (Southern Methodist University) y Nueva York (Universidad de Columbia). De regreso en Montevideo, enseñó derecho constitucional y derechos humanos ejerciendo al mismo tiempo funciones como experto en derecho internacional. Adicionalmente, fue consejero del Estado uruguayo en el marco del asunto de la "guerra del papel" ante la Corte Internacional de Justicia ${ }^{58}$, luego de haber trabajado como experto independiente ante la OIT y haber sido funcionario de Naciones Unidas entre 1977 y 1985.

Esta presentación de personalidades con carreras descomunales y formaciones diversas proporciona, sin duda, indicios importantes para tener una idea más precisa y técnica de su enfoque en términos de interpretación del derecho internacional. Indicios necesarios, que sin embargo no son suficientes. La lectura de sus votos particulares (concurrentes y disidentes) permitirá confirmar (o matizar) ciertas percepciones, para no hablar de intuiciones, relativas a su enfoque en materia de interpretación ${ }^{59}$.

\section{LAS TÉCNICAS DE INTERPRETACIÓN}

El enfoque evolutivo de la Convención reposa a la vez en una apertura normativa (es decir, una apertura significativa hacia las fuentes externas) (A), en la creación de nuevos derechos (B) y last but not least, en el uso de conceptos transformadores que aumentan las obligaciones impuestas a los Estados (C).

\section{A. La valorización de la apertura normativa}

El artículo 29.b) de la Convención, cuando postula la importancia de la interpretación pro-homine, induce a recurrir a múltiples fuentes exteriores para interpretar la Convención que ella designa, expressis verbis, como un "instrumento viviente" 60 . De repente, la Corte de San José relocaliza sistemáticamente la

58 El contencioso latinoamericano ante la CIJ ha gozado de un vigor imponente estos últimos años. El asunto de "la guerra del papel", llamado también "asunto Botnia", es una de sus manifestaciones. Este conflicto terminó con la sentencia de 20 de abril de 2010, Usines de pâtes à papier sur le fleuve Uruguay (Argentine c. Uruguay), CIJ, Recueil, 2010, p. 14.

59 Este punto será tratado particularmente en la tercera parte de este análisis, luego de haber descifrado las técnicas de interpretación de la Corte Interamericana.

60 Corte IDH, 19 de noviembre de 1999, Fondo, Villagrán Morales y otros ("Niños de la Calle") vs. Guatemala, Serie C No 63 párr. 193; Corte IDH, 8 de julio de 2004, Hermanos Gómez Paquiyauri vs. Perú, Serie C No 110, párr. 165. 
Convención no sólo en el "corpus iuris interamericano"61, sino también lo que ella denomina el "corpus iuris internacional". Dicho de otro modo, mientras el Tribunal Europeo habla de "consenso europeo" y a veces de consenso internacional, la Corte IDH prefiere expresiones como corpus iuris (latinoamericano o internacional) ${ }^{62}$. Aunque la terminología difiera, la técnica es idéntica ${ }^{63}$ : esta interpretación "abierta" de la Convención Americana está en sintonía con el enfoque "cosmopolita" desplegado por el Tribunal Europeo de Derechos Humanos ${ }^{64}$. La Corte de San José utiliza a la vez: tanto el derecho internacional vinculante ${ }^{65}$ como el soft law66; tanto la jurisprudencia internacional (universal y regional) como la jurisprudencia de las jurisdicciones internas (del continente americano ${ }^{67}$ o exteriores a éste); la doctrina de los comités convencionales (tanto interameri-

61 Véase supra.

62 Esto no quiere decir que la expresión "consenso" sea totalmente inexistente: véase, por ejemplo, Corte IDH, 19 de septiembre de 2009, Fondo y Reparaciones, Claude Reyes vs. Chile, párr. 78; sin embargo, es bastante escasa.

63 Para mayores matices, particularmente cronológicos, reenviamos a la tesis de RoTA, Marie (2013).

64 Reenviamos aquí a Burgorgue-Larsen, Laurence (2012 b), pp. 90-123.

65 Los tratados internacionales citados son a menudo tratados en vigor (ad ex., Convenio No 169 de la OIT, en particular en el marco del contencioso indígena, ad exemplum, Corte IDH, 27 de junio de 2012, Fondo y Reparación, Pueblo indígena Kichwa de Sarayaku vs. Ecuador, Serie C No 245, párr. 232). Esto no impide a la Corte utilizarlos, incluso cuando el Estado demandado no los ha ratificado. Sin embargo, los casos recientes demuestran que la Corte se esfuerza por destacar la ratificación de los tratados internacionales utilizados en su "interpretación de apertura" por parte del Estado concernido, para protegerse de las reacciones negativas por parte de los Estados.

66 En el caso de Humberto Sánchez, la Corte utilizó el "Protocolo de Minnesota" (Doc. NU/E/ST/ CSDHA/12, 1991) para determinar el alcance de la obligación de los Estados de llevar a cabo una investigación seria, imparcial y efectiva en términos de ejecución extrajudicial (Corte IDH, 7 de junio de 2003, Fondo, Humberto Sánchez vs. Honduras, Serie C No 99, párr. 127). Ella hizo lo mismo con respecto a la obligación del Estado relativa a los enfermos mentales: utilizó una resolución de la Asamblea General de las Naciones Unidas acerca de los Principios para la Protección de los Enfermos Mentales y el Mejoramiento de la Salud Mental (Doc. NU/A/46/49 [1991] Corte IDH, 4 de julio de 2006, Fondo y Reparaciones, Ximenes Lopes vs. Brasil, Serie C No 149, párr. 128).

67 Cabe señalar en este punto que los últimos años -es decir, desde la creación de una verdadera "teoría de control Convencionalidad" v. infra- la Corte destaca de manera particular el derecho constitucional de los Estados Parte de la OEA, y más específicamente la jurisprudencia de las cortes constitucionales. Las referencias recurrentes a las decisiones de la justicia nacional -que siempre vienen, evidentemente, combinadas con referencias a "los textos internacionales- tienen, en mi opinión, dos tipos de objetivos, además de ser obviamente una forma de legitimar el enfoque de interpretación de apertura. El primero es poner de relieve la existencia de un "patrimonio" común latinoamericano y el segundo, desarrollar un diálogo fructífero con los jueces nacionales. 
canos como universales) ${ }^{68}$; las reglas de buenas prácticas en ámbitos particulares (como la medicina legal, por ejemplo). En verdad, estamos lejos de los límites establecidos por el artículo 31.3 de la Convención sobre el derecho de los tratados que se refiere a todo "acuerdo" (31.3 a.) o "práctica" posteriores $(31.3 \mathrm{~b}$.) o a toda "forma pertinente" establecida entre las partes (31.3.c.) ${ }^{69}$.

Esta apertura a múltiples referentes exteriores tiene por objetivo principal interpretar tanto el contenido como el alcance de los derechos garantizados por la Convención Americana. La Corte lo ha afirmado claramente tratándose del artículo 19 sobre el derecho del niño: "Tanto la Convención Americana como la Convención sobre los Derechos del Niño forman parte de un muy comprensivo corpus juris internacional de protección de los niños que debe servir a esta Corte para fijar el contenido y los alcances de la disposición general definida en el artículo 19 de la Convención Americana"70. Aunque este dictum no se encuentra sistemáticamente en el resto del contencioso, la interpretación de la Corte tiene el mismo efecto.

Acotar el contenido de un derecho pasa tanto por la definición de las nociones "indefinidas" como por el descubrimiento de una o varias nuevas dimensiones, nociones y/o "categorías" en el seno del derecho. Por lo tanto, las nociones de "niño" (artículo 19), "tortura” (artículo 5), "propiedad” (artículo 21), "discriminación" (artículo 1.1) han podido ser definidas gracias a recursos y fuentes externas de diferente naturaleza. La Convención de Nueva York sobre los Derechos del Niño dio la posibilidad a la Corte Interamericana de considerar que un niño es "cualquier persona que no ha alcanzado la edad de 18 años" 71 , el uso de la jurisprudencia del Tribunal Penal Internacional para ex Yugoslavia (TPIY) y del

68 Ad ex., Corte IDH, Fondo y Reparaciones, 24 de agosto de 2010, Comunidad Indígena Xákmok Kásek vs. Paraguay, Serie C No 214, párrs. 215, 216, 194-217. La Corte cita en particular la "doctrina" del Comité de Derechos Económicos, Sociales y Culturales de Naciones Unidas: CDESC, Observación General No 15 (derecho al agua, artículos 11 y 12 del Pacto), 29º período de sesiones de 2002, HRI/GEN/1/Rev.7 en 117 (2002); CDESC, Observación General No 12, 12 de mayo de 1999, E/C.12/1999/5, párrs. 6-8; CDESC, Observación General No 13, 8 de diciembre de 1999, E/C.12/1999/10, párr. 50; CDESC, Observación General No 21, 21 de diciembre de 2009, E/C.12/GC/21, párr. 38.

69 Para una crítica virulenta sobre el rebasamiento de las reglas impuestas por la Convención de Viena, véase Neuman, Gerald (2008), pp. 101-123; contra Lixinski, L. (2010), pp. 585-604. Para un estudio pionero y muy sutil, ver Carozza G., Paolo (1998), pp. 12-17-1238.

70 Corte IDH, 19 de noviembre de 1999, Fondo, Villagrán Morales y otros ("Niños de la Calle") vs. Guatemala, Serie C No 63, párr. 188.

71 Corte IDH, 19 de noviembre de 1999, Fondo, Villagrán Morales y otros ("Niños de la Calle") vs. Guatemala, Serie C No 63, párr. 188. 
TEDH permitió integrar múltiples actos de violencia -incluyendo la violación sexual- en la definición de la tortura ${ }^{72}$, mientras que las disposiciones de la Convención Interamericana contra la Tortura permitieron identificar con precisión el concepto como tal; el uso de los trabajos preparatorios de la Convención Americana, asociado al artículo 29.b), ha permitido otorgar un contenido "comunitario" a la noción de propiedad ${ }^{73}$; el recurso a la jurisprudencia del TEDH y a la "doctrina" del Comité de Derechos Humanos ha permitido definir de manera extensiva la noción de discriminación ${ }^{74}$. Este proceso de definición de nociones "indefinidas" ha tenido como consecuencia, de manera evidente, extender el campo de aplicación de la Convención ${ }^{75}$. Este fenómeno no siempre pasa por esta operación de definición. También puede ocurrir gracias al descubrimiento de una nueva dimensión y/o de una nueva categoría de un derecho protegido. Así, la Corte llegó a la conclusión en el famoso caso Atala Riffo de que la orientación sexual y la identidad de género eran "categorías protegidas por el artículo 1.1" que trata de no discriminación ${ }^{76}$. Asimismo, impulsó tempranamente la teoría de la

72 Corte IDH, 25 de noviembre de 2006, Fondo y Reparaciones, Prisión Miguel Castro Castro vs. Perú, Serie C No 160, párr. 312.

73 Corte IDH, 31 de agosto de 2001, Fondo y Reparaciones, Comunidad Mayagna (Sumo) Awas Tigni vs. Nicaragua, Serie C No 79 .

74 Corte IDH, 24 de febrero de 2012, Fondo y Reparaciones, Atala Riffo e hijas vs. Chile, Serie C № 239, párr. 81. La Corte recuerda claramente que la doctrina del Comité se basa directamente en las definiciones de los artículos 1.1 de la Convención sobre la Eliminación de todas las formas de Discriminación Racial y la Convención sobre la Eliminación de todas las Formas de Discriminación contra las Mujeres.

$75 \mathrm{Al}$ igual que el artículo 14 de la Convención Europea, el artículo 1.1 de la Convención Americana -que enumera una serie de motivos de no discriminación- no menciona la orientación sexual. Se trata, sin embargo, de una cláusula "abierta" que termina con la frase "o cualquier otra condición social"... Por lo tanto, la Corte, haciendo uso de esta incisión final y apoyándose en la soft law de la Asamblea General de la OEA, en la jurisprudencia europea (Salgueiro da Mouta y Cilfit), en la doctrina de la Comisión de Derechos Humanos, del Comité de Derechos Económicos y Sociales y de otros Comités Convencionales, ha considerado que el motivo de no discriminación por razón de orientación sexual debe incluirse en las "categorías" a que se refiere el artículo 1.1 de la Convención Americana.

76 El párrafo 82 de la sentencia Atala Riffo en este sentido es característico: "La Corte reitera que, mientras la obligación general del artículo 1.1 se refiere al deber del Estado de respetar y garantizar 'sin discriminación' los derechos contenidos en la Convención Americana, el artículo 24 protege el derecho a 'igual protección de la ley'. Es decir, el artículo 24 de la Convención Americana prohíbe la discriminación de derecho o de hecho, no sólo en cuanto a los derechos consagrados en dicho tratado, sino en lo que respecta a todas las leyes que apruebe el Estado y a su aplicación. En otras palabras, si un Estado discrimina en el respeto o garantía de un derecho convencional, incumpliría la obligación establecida en el artículo 1.1 y el derecho sustantivo en cuestión. Si, por el contrario, la discriminación se refiere a una protección desigual de la ley interna o su aplicación, el hecho debe analizarse a la luz del artículo 24 de la Convención Americana”. 
"doble dimensión" de los derechos, tanto individual como social, que tiene como consecuencia automática ampliar considerablemente el contenido del derecho de que se trate. Es en el contexto del litigio relativo a la libertad de expresión donde la Corte desarrolló este enfoque ${ }^{77}$.

Identificar el alcance de un derecho es la otra faceta de la interpretación evolutiva y se caracteriza por la toma en consideración de ciertos contextos específicos del continente latinoamericano. La idea importante aquí, sobre la que es necesario insistir, es la idea de eficacia. La Corte hará todo lo posible para que los derechos consagrados en el texto del tratado tengan un alcance concreto y efectivo en el contexto eminentemente complejo y violento de la realidad latinoamericana. En pocas palabras, se trata de la teoría del efecto útil, llevada a su paroxismo. Así, el alcance del derecho de la propiedad (artículo 21), del derecho de libre circulación (artículo 22) o del derecho a la vida (artículo 4) ha sido establecido en un contexto específico de conflictos armados internos gracias a la utilización, como instrumentos interpretativos ${ }^{78}$, de los principios del derecho internacional humanitario ${ }^{79}$. En consecuencia, la Corte se encuentra en capacidad de abordar

\footnotetext{
77 Entre la determinación de múltiples dimensiones de un derecho y la ampliación de su alcance hay una frontera tenue que no es, en este sentido, bien delimitada por la Corte en todos los casos.

78 Es necesario recordar el distingo entre interpretación y aplicación. La Corte ha rehusado sistemáticamente aplicar como tal el derecho internacional humanitario considerando que ella no tiene competencia para determinar la compatibilidad de los actos de los Estados con los Convenios de Ginebra y/o sus Protocolos de 1977 (Corte IDH, 4 de febrero de 2000, Excepciones Preliminares, Las Palmeras vs. Colombia, Serie C No 67, párr. 33). En contraste, utilizar el derecho internacional humanitario con fines de interpretación de la Convención Americana siempre ha sido considerado de alta importancia (Corte IDH, 23 de noviembre de 2004, Excepciones Preliminares, Hermanas Serrano Cruz vs. El Salvador, Serie C No 118; Corte IDH, 1 de marzo de 2005, Fondo y Reparaciones, Hermanas Serrano Cruz vs. El Salvador, Serie C No 120; Corte IDH, 7 de marzo de 2005, Fondo y Reparaciones, Masacre de Mapiripán vs. Colombia, Serie C No 122; Corte IDH, 24 de noviembre de 2009, Excepciones Preliminares, Fondo y Reparaciones, Masacre de Las Dos Erres vs. Guatemala, Serie C No 211).

79 Como lo plantean los Convenios de Ginebra de 1977, los Protocolos de 1977 y el derecho internacional consuetudinario. En el caso de las Masacres de Ituango, los derechos a la propiedad privada (artículo 21) y la libertad de circulación (artículo 22) son analizados a la luz del Protocolo II de 8 de junio de 1977 de los Convenios de Ginebra. Este análisis permite a la Corte constatar "una grave privación del uso y goce de los bienes" de los habitantes del corregimiento de El Aro y al mismo tiempo una "violación de los derechos consagrados en el artículo 22, en relación con el artículo 1.1 de la Convención Americana, con respecto a 702 personas desplazadas". Corte IDH, 1 de julio de 2006, Fondo y Reparaciones, Masacres de Ituango vs. Colombia, Serie C No 148, parr. 179. La Corte hace notar particularmente en el párrafo 180 la importancia de los artículos 13 (protección de la población civil) y 14 (protección de los bienes indispensables para la supervivencia de la población civil) del Protocolo II, que prohíben, respectivamente, "los actos o amenazas de violencia cuya finalidad principal es la de aterrorizar a la población civil", como el hecho de "para atacar, destruir, sustraer [...] los bienes esenciales para la supervivencia de la población civil". Y en el proceso
} 
de manera pertinente el problema del desplazamiento forzado ${ }^{80}$, así como los bombardeos contra la población civil sin el debido respeto de los principios de distinción, proporcionalidad y precaución inherentes al derecho internacional humanitario $^{81}$. Del mismo modo, la Corte ha dotado numerosos derechos de la Convención de un alcance colectivo y multicultural que tome nota del "hecho indígena" en todas sus dimensiones. Así pues, el derecho a la vida (artículo 4) se halla sistemáticamente transformado, en los asuntos indígenas, en el derecho a vivir "dignamente" 82 ; el derecho a la libertad de expresión (artículo 13) incluye el derecho a hablar, para los indígenas, en su propio idioma, porque éste "garantiza la expresión, la distribución y transmisión de la cultura" ${ }^{83}$; el derecho a la participación política (artículo 23) y a la igualdad ante la ley (artículo 24) han sido interpretados de tal forma que las modalidades tradicionales de organización comunitaria han sido asimiladas a partidos políticos a fin de que las comunidades indígenas puedan participar en la vida democrática de su país ${ }^{84}$, etc. El contencioso ha demostrado que los "usos y las costumbres tradicionales" son tomados en serio por la Corte, quien acepta que la "cosmovisión" indígena irrigue la evaluación de los derechos protegidos, incluso cuando esto puede "chocar" con la visión occidental de los derechos ${ }^{85}$.

La especificidad latinoamericana no se encuentra sistemáticamente al origen de la determinación del alcance de un derecho. El derecho a la "vida privada" (artículo 11. Protección de la Honra y de la Dignidad) es importante en este sentido. Asistimos, en la jurisprudencia de la Corte Interamericana, a una amplia-

(párr. 182), la Corte afirmó que "el propósito del incendio y la destrucción de las casas de los habitantes de El Aro fue crear terror y provocar su desplazamiento para conseguir una victoria territorial en la lucha contra la guerrilla en Colombia". Por lo tanto, "la confiscación de ganado y la destrucción de viviendas por parte de paramilitares, perpetrada con la colaboración directa de los agentes del Estado constituye una grave privación del uso y el goce de los bienes" (párr. 183).

80 Thiele, B (2003), pp. 463-477.

81 Corte IDH, 30 de noviembre de 2012, Excepciones Preliminares, Fondo y Reparaciones, Masacre de Santo Domingo vs. Colombia, Serie C No 259.

82 Corte IDH, 29 de marzo de 2006, Fondo y Reparaciones, Comunidad Indígena Sawhoyamaxa vs. Paraguay, Serie C No 146.

83 Corte IDH, 1 de febrero de 2006, Fondo y Reparaciones, López Álvarez vs. Honduras, Serie C No 141, párr. 171.

84 Corte IDH, 23 de junio de 2005, Yatama vs. Nicaragua, Serie C No 127, párr. 215.

85 En el famoso asunto Aloeboetoe, la Corte otorgó reparaciones a las diferentes mujeres del muerto según los "usos y costumbres de la Comunidad en la cual vivía". Corte IDH, 10 de septiembre de 1993, Reparaciones, Aloeboetoe y otros c. Suriname, Serie C No 15. 
ción consecuente del contenido de este derecho; y para esto, la referencia externa utilizada no es, ni más ni menos, que la jurisprudencia del TEDH que, gracias a la "dilución" del concepto de vida privada, ha sido llevada a incorporar muchos elementos. El parágrafo 143 de la sentencia emitida en el caso de la Fecundación in vitro es significativo a este respecto: se nota no sólo la ampliación del ámbito de aplicación del derecho, sino también la importación de nociones como la de autonomía y de desarrollo personal:

"El ámbito de protección del derecho a la vida privada ha sido interpretado en términos amplios por los tribunales internacionales de derechos humanos, al señalar que éste va más allá del derecho a la privacidad. La protección a la vida privada abarca una serie de factores relacionados con la dignidad del individuo, incluyendo, por ejemplo, la capacidad para desarrollar la propia personalidad y aspiraciones, determinar su propia identidad y definir sus propias relaciones personales. El concepto de vida privada engloba aspectos de la identidad física y social, incluyendo el derecho a la autonomía personal, desarrollo personal y el derecho a establecer y desarrollar relaciones con otros seres humanos y con el mundo exterior ${ }^{80 "}$.

\section{B. La creación de nuevos derechos}

Gracias a la técnica general de interpretación que consiste en derribar las separaciones normativas a todos los niveles, hemos visto que el contenido y el alcance de los derechos han podido ser precisados al punto de traer consigo un aumento bastante sustancial del ámbito de aplicación de la Convención. Ahora bien, cuando esta técnica general se combina con técnicas específicas -a saber, la técnica de la "integración” por un lado y la de la combinación de las bases jurídicas por el otro- los resultados son aún más sorprendentes. Se trata, ni más ni menos, que de "crear" nuevos derechos. Sin embargo -y aquí es donde la Corte es particularmente astuta-, ella vincula sistemáticamente estos "nuevos derechos" a uno o más fundamentos jurídicos preexistentes en el seno de la Convención Americana. Para comprender adecuadamente este proceso interpretativo, podríamos hablar de una "revelación" de derechos que estarían consagrados implícitamente en el texto convencional y que la Corte simplemente "desvela" públicamente. Así pues, aunque en ninguna parte del texto son "nombrados", estos derechos terminan por ser desvelados, nombrados y, por lo tanto, creados.

86 Corte IDH, Fecundación in vitro, párr. 143. 
La primera técnica -la "técnica de la integración"- se manifestó en el marco del contencioso de las desapariciones forzadas. La sentencia fundamental fue sentencia Bámaca Velásquez, de 25 de noviembre de 2000. La Corte consideró expresamente que el derecho a la verdad estaba "integrado" a los artículos 8 y 25 de la Convención que consagran, respectivamente, el derecho a un juicio justo (derecho a un juicio justo) y a la protección judicial (derecho a la protección judicial) 87 . Después de la presión ejercida durante casi veinte años por la Comisión ${ }^{88}$, la Corte reconoció en el caso Araguaia que aquél se deriva igualmente del artículo 13 (derecho de información) ${ }^{89}$. La segunda técnica consiste en combinar varios fundamentos jurídicos: existentes en el seno de la Convención Americana (combinación intraconvencional) o en la Convención y otros instrumentos internacionales (combinación interconvencional). Se podría argumentar que se trata de la técnica clásica de la interpretación sistemática. En realidad, el enfoque sistemático sirve como base a la técnica de combinación normativa que es, por su parte, mucho más precisa.

El contencioso "indígena" es característico de la técnica combinatoria intraconvencional. En el caso del Pueblo Saramaka ${ }^{90}$, el derecho a la consulta previa,

87 Los párrafos 201 y 202 de la sentencia de fondo en el caso Bámaca Velásquez son claros: (párr. 201): "De todos modos, en las circunstancias del presente caso, el derecho a la verdad se encuentra subsumido en el derecho de la víctima o sus familiares a obtener de los órganos competentes del Estado el esclarecimiento de los hechos violatorios y las responsabilidades correspondientes, a través de la investigación y el juzgamiento que previenen los artículos 8 y 25 de la Convención" (párr. 202): "Por lo tanto, esta cuestión queda resuelta con lo establecido en el capítulo anterior, en relación con las garantías judiciales y la protección judicial”. Corte IDH, 25 de noviembre de 2000, Bámaca Velásquez vs. Guatemala, Serie C No 70.

88 En el caso Barrios Altos, la Comisión había alegado la violación del derecho a la verdad. Su argumento fue presentado en el Capítulo VIII, titulado "Derecho a la Verdad y garantías judiciales de los estados la ley". Ella invocó, junto con los artículos 8 y 25 -considerados como "instrumentos decisivos en el establecimiento judicial de los hechos”- el artículo 13.1 en materia de libertad de expresión. Y afirmó que esta disposición "reconoce el derecho a buscar y recibir información" y que, en virtud de su contenido, el Estado tiene una "obligación positiva de garantizar información esencial para proteger los derechos de las víctimas, garantizando la transparencia de la gestión estatal y la protección de los derechos humanos". Su táctica judicial fue un fracaso en la época. Para obtener más información, véase Burgorgue-LARSEn, Laurence; Úbeda De Torres, Amaya (2011 a); Chapter 27, The right to the truth, LBL.

89 Corte IDH, 24 de noviembre de 2010, Excepciones Preliminares, Fondo y Reparaciones, Gomes Lund y otros (Guerrilha do Araguaia) vs. Brasil, Serie C No 219, párr. 201. La Corte en el caso Gelman (Corte IDH, 24 de febrero de 2011, Fondo y Reparaciones, Gelman vs. Uruguay, Serie C No 221) confirmó el vínculo del derecho a la verdad con el artículo 13 de la Convención Americana en el párrafo 243 y en la nota 301 de su sentencia.

90 Corte IDH, 12 de agosto de 2008, Interpretación, Pueblo de Saramaka vs. Suriname, Serie C No 185, párrs. 11 y 18. 
libre e informada fue derivado del artículo 21 en relación con los artículos 1.1 y 2 de la Convención Americana. En otras palabras, este derecho se deriva de la obligación estatal de asegurar la participación efectiva de los pueblos indígenas y tribales en cualquier tipo de proyecto de desarrollo, inversión, exploración o explotación previsto dentro de sus territorios tradicionales. La Corte considera incluso que se trata, en nuestros días, de un "principio general del derecho internacional"91. En el importante caso del Pueblo Indigena Kichwa de Sarayaku combinó el artículo 21 con los artículos 1.1 y 29.b para derivar el derecho a la identidad cultural ${ }^{92}$, señalando, sin rodeos, su naturaleza colectiva ${ }^{93}$. Lo mismo puede decirse en relación con el derecho a la vida familiar. La Corte, en el caso de la Fecundación in vitro, combinó los artículos 11.2 (derecho a la intimidad) y el artículo 17.2 (derecho de familia) para preguntarse por la existencia del derecho a fundar una familia, el derecho a la "reproducción autónoma" y el derecho de acceso a las mejores técnicas de reproducción asistida ${ }^{94}$.

La otra técnica combinatoria consiste en utilizar un instrumento exógeno a la Convención Americana y vincularlo a un derecho contenido en ella. El caso Gelman ${ }^{95}$ es emblemático de esta técnica combinatoria interconvencional, adi-

91 Corte IDH, 27 de junio de 2012, Fondo y Reparaciones, Pueblo Indígena Kichwa de Sarayaku vs. Ecuador, Serie C No 245, párr. 164: "Es decir, la obligación de consulta, además de constituir una norma convencional, es también un principio general del Derecho Internacional".

92 Corte IDH, 27 de junio de 2012, Fondo y Reparaciones, Pueblo Indígena Kichwa de Sarayaku vs. Ecuador, Serie C No 245, párr. 213: "Bajo el principio de no discriminación, establecido en el artículo 1.1 de la Convención, el reconocimiento del derecho a la identidad cultural es ingrediente y vía de interpretación transversal para concebir, respetar y garantizar el goce y ejercicio de los derechos humanos de los pueblos y comunidades indígenas protegidos por la Convención y, según el artículo 29.b) de la misma, también por los ordenamientos jurídicos internos".

93 Corte IDH, 27 de junio de 2012, Fondo y Reparaciones, Pueblo Indígena Kichwa de Sarayaku vs. Ecuador, Serie C No 245, párr. 217: "La Corte considera que el derecho a la identidad cultural es un derecho fundamental y de naturaleza colectiva de las comunidades indígenas, que debe ser respetado en una sociedad multicultural, pluralista y democrática”.

94 Corte IDH, 28 de noviembre de 2012, Excepciones Preliminares, Fondo y Reparaciones, Artavia Murillo y otros (Fecundación in vitro) vs. Costa Rica, Serie C No 257, párr. 150: "Por tanto, y conforme al artículo 29 b) de la Convención Americana, el alcance de los derechos a la vida privada, autonomía reproductiva y a fundar una familia, derivado de los artículos 11.2 y 17.2 de la Convención Americana, se extiende al derecho de toda persona a beneficiarse del progreso científico y de sus aplicaciones. Del derecho de acceso al más alto y efectivo progreso científico para el ejercicio de la autonomía reproductiva y la posibilidad de formar una familia se deriva el derecho a acceder a los mejores servicios de salud en técnicas de asistencia reproductiva, y, en consecuencia, la prohibición de restricciones desproporcionadas e innecesarias de iure o de facto para ejercer las decisiones reproductivas que correspondan en cada persona".

95 Corte IDH, 24 de febrero de 2011, Fondo y Reparaciones, Gelman vs. Uruguay, Serie C No 221, párr. 122. 
cionalmente en un caso que pone en evidencia para el mundo judicial una vez más las atrocidades perpetradas por el terrorismo de Estado. Así, en relación con la desaparición forzada de una joven mujer embarazada -que repercutió automáticamente en el hijo de la desaparecida, separado de su madre y entregado a las familias de militares ${ }^{96}$ - la Corte dedujo un "derecho a la identidad". La combinación normativa se apoya en el artículo 19 de la Convención (derechos del niño) puesto directamente en relación con los artículos 3 (derecho a la personalidad jurídica), 17 (protección a la familia), 18 (derecho al nombre) y 20 (derecho a la nacionalidad) del texto e interpretado en relación con varias disposiciones de la Convención sobre los Derechos del Niño ${ }^{97}$. Esta técnica también se ha hecho evidente en los casos en que ha existido la necesidad de analizar los derechos existentes bajo una perspectiva innovadora -en el caso, una perspectiva ambientalista- en vez de realmente creadora. De todos modos, esto presagia, sin duda, la consagración, tarde o temprano, del derecho a vivir en un medio ambiente sano ${ }^{98}$.

96 Se trata, para la Corte de una "forma de desaparición forzada". Corte IDH, 24 de febrero de 2011, Fondo y Reparaciones, Gelman vs. Uruguay, Serie C No 221, párr. 132: "En mérito de lo anterior, la sustracción, supresión y sustitución de identidad de María Macarena Gelman García como consecuencia de la detención y posterior traslado de su madre embarazada a otro Estado pueden calificarse como una forma particular de desaparición forzada de personas, por haber tenido el mismo propósito o efecto, al dejar la incógnita por la falta de información sobre su destino o paradero o la negativa a reconocerlo, en los propios términos de la referida Convención Interamericana”.

97 Corte IDH, 24 de febrero de 2011, Fondo y Reparaciones, Gelman vs. Uruguay, Serie C No 221, párrs. $121 \mathrm{y}$ ss.

98 Corte IDH, 3 de abril de 2009, Fondo y Reparaciones, Kawás Fernández vs. Honduras, Serie C No 196. En el marco del estudio de la violación del artículo 16 (libertad de asociación), la jurisdicción interamericana no vaciló, como es su costumbre, en movilizar una serie de referencias endógenas (es decir, propias al sistema político y jurídico de la OEA) y exógenas (totalmente exteriores al continente americano) con el fin de afirmar que "existe una relación innegable entre la protección del medio ambiente y la realización de otros derechos humanos" (párr. 148). Además de valorar la jurisprudencia europea-los casos Guerra, López Ostra, Fadeyeva- y de recordar su propia jurisprudencia en el marco del contencioso indígena, así como el reconocimiento constitucional del medio ambiente en numerosos países del continente americano, la Corte hizo referencia a los trabajos de la Asamblea General de la OEA y de las Naciones Unidas. Estos últimos pusieron en evidencia la manera como la degradación del medio ambiente y sus efectos perversos en materia de cambio climático han afectado el goce efectivo de los derechos humanos en el continente. Y para coronar esta profesión de fe, reafirmó el reconocimiento de los vínculos existentes entre el respeto de los derechos humanos y la protección del medio ambiente, y sus múltiples avances consagrados en el Protocolo de San Salvador. El derecho al medio ambiente sano será así inscrito como parte del artículo 11.1, que estipula que: "Toda persona tiene derecho a vivir en un medio ambiente sano y a contar con servicios públicos básicos". La táctica de la Corte aquí es muy interesante y conviene destacarla. El Protocolo Adicional a la Convención Americana no hace que el derecho al medio ambiente sea exigible, "sólo" lo protege mediante informes periódicos que los Estados Parte deben remitir a la Comisión Interamericana (artículo 19.6). Sin embargo, la Corte no expone este elemento de procedimiento y sólo se apega a los contenidos del Protocolo. Es una 


\section{La utilización de conceptos "transformadores"}

Dos "conceptos" de posibilidades infinitas están en el centro de una política judicial especialmente "comprometida": el primero es un "derecho" protegido por la Convención -el derecho a la no discriminación (artículo 1.1), con su corolario positivo, la igualdad (artículo 24)-, el otro es un concepto pretoriano (vulnerabilidad) surgido al filo de su jurisprudencia. Ellos sirven no sólo para poner fin a las desigualdades de tipo estructural, sino también para imponer a los Estados obligaciones positivas reforzadas. De repente, ya no se trata de extender el campo de aplicación de la Convención como tal, sino el alcance de las obligaciones impuestas a los Estados. Ambos, estrechamente relacionados: podría decirse que son dos caras de la misma moneda.

La Corte Interamericana ha aprovechado la presencia en la Convención Americana del principio de no discriminación (artículo 1.1) para poner fin a las situaciones estructurales en las que los individuos y/o grupos han sufrido desde una perspectiva histórica, sociológica, económica, o incluso política, una conducta "discriminatoria". Así, podemos considerar que se ha construido un verdadero "derecho indígena" sobre la base del principio de no discriminación. Esta presencia también se ha utilizado en la lucha contra los estereotipos contra los homosexuales (caso Atala Riffo) y contra aquellos que afectan a los trabajadores migrantes (opinión $N^{o} 18$ sobre los migrantes indocumentados) o a los niños (opinión $N^{o} 17$ sobre los derechos del niño) para que beneficien de una protección jurídica elemental.

En este contexto, la vulnerabilidad refuerza de alguna manera el juego del derecho a la no discriminación permitiendo imponer a los Estados una serie de obligaciones positivas. Los niños, junto con las mujeres, los detenidos, las comunidades indígenas, los indocumentados, los defensores de derechos humanos, han sido repetidamente calificados como "vulnerables" por la Corte de San José. Una cartografía de la vulnerabilidad permite afinar este análisis ${ }^{99}$. A partir de ella puede descubrirse que la jurisprudencia de la Corte Interamericana distingue individuos o grupos de personas vulnerables a partir de su condición

\footnotetext{
manera de importar, en el regazo de su jurisprudencia, la protección del medio ambiente que, de repente, va a convertirse en un parámetro de interpretación. La muerte de Jeannette Kawás Fernández fue considerada por la Corte de manera "evidente" como una "privación de su derecho a la libertad de asociación" (párr. 152). Y debemos recordar el efecto inhibidor de este tipo de delitos sobre "otras personas que se dedican a la protección del medio ambiente en Honduras o se relacionan con este tipo de causas” (párr. 153). Es en este contexto que fue constatada la violación del artículo 16.1 (libertad de asociación) en relación con el artículo 1.1. Las estrategias de protección indirecta del medio ambiente y de las personas que se preocupan por ella no podían aparecer de manera más vibrante. El ingenio legal estaba en su apogeo.
}

99 Estupinan-Silva, Rosmerlin (2014), pp. 89-113. 
personal (niños, mujeres, minorías sexuales, comunidades indígenas, personas con discapacidad) y/o a partir de la existencia de una situación específica (migrantes, personas en detención, líderes de oposición, defensores de derechos humanos, personas desplazadas, periodistas). En este último caso, la vulnerabilidad es un "agravante". Por lo tanto, el niño será más vulnerable durante los conflictos armados o si se trata de un niño indígena, si se encuentra en situación de detención o si sufre de alguna discapacidad. La misma constatación puede hacerse en el caso de los defensores de derechos humanos, cuya vulnerabilidad se agrava en la perspectiva de la Corte cuando se trata de sindicalistas, campesinos, indígenas o incluso mujeres.

En este contexto, la vulnerabilidad supone "la adopción de medidas especiales para garantizar su protección”. En efecto, la Corte no ha tenido ninguna dificultad para consagrar una concepción sustancial de la igualdad, afirmando que "es indispensable reconocer y respetar las diferencias de trato que corresponden a diferentes situaciones"100. Esta visión de la igualdad fue de hecho desarrollada, incluso conceptualizada, en una muy importante opinión de 2002101. La Corte de San José declaró en particular que "hay ciertas desigualdades que pueden traducirse legítimamente en desigualdades de tratamiento jurídico, sin que esto sea contrario a la justicia" (pará. 46). Estimando que "en virtud de los artículos 1 y 24 de la Convención Americana, los Estados no pueden establecer diferencias que carezcan de una justificación objetiva y razonable y no tengan como propósito único, en definitiva, el ejercicio de los derechos allí consagrados" (pará. 55).

Es interesante en este punto subrayar que los principios de igualdad ante la ley y de no discriminación ${ }^{102}$ fueron considerados por la Corte IDH como normas de jus cogens. Este fenómeno es, sin duda alguna, un sello de la especificidad de la jurisprudencia interamericana. Además de la prohibición de la tortura-que ya no es objeto actual de discusión ${ }^{103}$, , la Corte Interamericana también ha reconocido

100 Corte IDH, 19 de noviembre de 1999, Fondo, Villagrán Morales y otros ("Niños de la Calle") vs. Guatemala, Serie C No 63, párr. 96.

101 Corte IDH, 28 de agosto de 2002, Opinión Consultiva, Condición jurídica y derechos humanos del niño, Serie A No 17. Para un análisis profundo en francés de esta opinión y del caso Villagrán Morales y otros (“Niños de la Calle”), v. Martin-Chenut, Kathia (2008), pp. 415-428.

102 Corte IDH, 17 de septiembre de 2003, Opinión Consultiva, Condición jurídica y derechos de los trabajadores migrantes indocumentados, Serie A No 18, párr. 101.

103 No hay discusión, puesto que las jurisdicciones internacionales tienen una jurisprudencia unificada a este respecto: fue el Tribunal Penal Internacional para la antigua Yugoslavia (TPIY) quien decretó por primera vez en 1998 que la prohibición de la tortura era una norma de jus cogens (TPIY, 10 de diciembre de 1998, 
que la imprescriptibilidad de los crímenes contra la humanidad ${ }^{104}$, la prohibición de las desapariciones forzadas y la obligación correlativa de perseguir y sancionar a los responsables ${ }^{105}$ son normas de jus cogens. Se trata de una nomenclatura original que está lejos de convencer a la doctrina internacionalista "clásica" todavía ampliamente dominante ${ }^{106}$. Lo cierto es que la presencia de Antônio Cançado Trindade en el seno de la Corte contribuyó ampliamente en la identificación de dichas normas. Este es el juez que, de manera más evidente, nunca cejó en su tarea de vincular sus convicciones y posiciones académicas a su función judicial.

\section{LAS CONSECUENCIAS DE LA INTERPRETACIÓN}

Como parte de los desarrollos que siguen, he identificado tres tipos de consecuencias que la interpretación evolutiva de la Corte Interamericana puede generar. Si la primera de ellas está demostrada y puede darse por sentada (A), no puede afirmarse lo mismo de las otras dos (B y C, las consecuencias institucionales y políticas). Lo que aquí presento, en la ocurrencia, son algunas pistas para la reflexión y no datos definitivos.

\section{A. Las consecuencias técnicas}

La interpretación evolutiva es una manera de mantenerse al día con las tendencias convergentes a escala internacional. Se trata, de alguna manera, de mantener viva la universalidad de los derechos ${ }^{107}$. Este aspecto es importante, pero no es específico del sistema interamericano ${ }^{108}$. Sin embargo, el establecimiento de

Prosecutor vs. Furundzija). Acto seguido, el TEDH en 2001 (TEDH, 21 de noviembre de 2001, Al-Adsani vs. Reino Unido) y la Corte IDH en 2003 (Corte IDH, 27 de noviembre de 2003, Fondo y Reparaciones, Maritza Urrutia vs. Guatemala, Serie C No 103). La Corte IDH confirmó este punto varias veces: Corte IDH, 11 de marzo de 2005, Fondo y Reparaciones, Caesar vs. Trinidad y Tobago, Serie C No 123; Corte IDH, 11 de mayo de 2007, Fondo y Reparaciones, Bueno Alves vs. Argentina, Serie C No 164; Corte IDH, 30 de octubre de 2008, Excepciones Preliminares, Fondo y Reparaciones, Bayarri vs. Argentina, Serie C No 187. 104 Corte IDH, 26 de septiembre de 2006, Fondo y Reparaciones, Almonacid Arellano y otros vs. Chile, Serie C No 154, párr. 153.

105 Corte IDH, 22 de septiembre de 2006, Fondo y Reparaciones, Goiburu vs. Paraguay, Serie C No 153, párrs. 84, 93, 128 y 131.

106 Para un análisis crítico más bien contundente, véase AbELlo-Galvis, R. (2012), pp. 357-375.

107 Es a lo menos lo que defiendo en un artículo escrito en homenaje al profesor FLAUSS, J-F, desgraciadamente fallecido demasiado temprano (2014), pp. 101-115.

108 Podríamos, en efecto, sacar la misma conclusión para el Tribunal Europeo de los Derechos Humanos. 
“control de convencionalidad" a partir de 2006109 , por su parte, está enteramente ligado a la originalidad del sistema interamericano. Aquél se basa en la necesidad de interpretar los derechos en relación con el principio pro-homine; dicho de otro modo, su objetivo es garantizar la debida consideración de las sentencias de la Corte por parte de los jueces nacionales.

El control de convencionalidad ha sido objeto de un desarrollo teórico excepcional por parte del juez ad hoc mexicano Eduardo Ferrer Mac-Gregor, cuando fuera designado por el gobierno para sesionar en el caso Cabrera García y Montiel Flores, de 26 de noviembre de $2010^{110}$. El juez ad hoc presentó entonces con habilidad y resolución un estado del arte preciso acerca de los diversos aspectos del control de convencionalidad en América Latina, un tema que hoy irriga la literatura jurídica del continente americano ${ }^{111}$. Durante la lectura de dicho texto, cualquier lector puede entender que se está en presencia ni más ni menos que de una teoría del control de convencionalidad que está destinada a servir como guía para cualquier órgano judicial del continente ${ }^{112}$. Esta teoría establece una distinción entre el llamado control "concentrado" de convencionalidad -que está en manos de la Corte de San José, intérprete natural de la Convención Americana- y un llamado control "difuso" que, por su parte, se encuentra en manos de todos los tribunales nacionales que deben actuar como "jueces convencionales de derecho común” cuando tienen que resolver casos en los que el derecho internacional es aplicable. Consciente de las dificultades de aplicación

109 Corte IDH, 26 de septiembre de 2006, Fondo y Reparaciones, Almonacid Arellano y otros vs. Chile, Serie C No 154. Esta sentencia confirma la prohibición del fenómeno de las amnistías para graves violaciones de derechos humanos.

110 Corte IDH, 26 de noviembre de 2010, Excepciones Preliminares, Fondo y Reparaciones, Cabrera García y Montiel Flores vs. México, Serie C No 220.

111 Ayala Corao, Carlos (2012), p. 295; Rey Cantor, Ernesto (2008); Ferrer Mac-Gregor, Eduardo, Herrera García, A. (2013 b), p. 1412; García Morelos (2010). Señalamos igualmente los artículos del jurista argentino Néstor Pedro Sagüés, SAGǗs, Néstor Pedro (2010 a), (2010 b) y (2011), pp. 381-417. Para un análisis que pone en perspectiva las dificultades de tal control vis-à-vis las especificidades de un sistema constitucional preciso: CASTILla, Karlos (2011), pp. 593-624.

112 Es sintomático constatar que esta opinión separada fue introducida in extenso como un artículo de doctrina en múltiples revistas, por ejemplo: el Boletín Mexicano de Derecho comparado, 2011, № 131, pp. 917-967. Es conveniente subrayar que el profesor Ferrer Mac-Gregor es un constitucionalista mexicano de renombre que dirige, por ejemplo, la Revista Iberoamericana de Derecho Procesal Constitucional que publica desde hace numerosos años análisis constitucionales en torno a esta temática del control de convencionalidad. Sus trabajos personales demuestran, por otra parte, que se ha dedicado evidentemente con anterioridad a esta reflexión. Por ejemplo, Ferrer Mac-Gregor, Eduardo (2010), pp. 151-188. 
de esta obligación en el marco del mosaico constitucional del continente y de la variedad de competencias de los jueces nacionales, el juez ad hoc desarrolló las opciones posibles y las sintetizó en el párrafo 41 de su opinión separada. En efecto, se analizan los diferentes niveles de "intensidad" de este control. El primer grado de intensidad se caracteriza por la obligación de interpretar el derecho nacional a la luz del conjunto del corpus iuris interamericano tal como ha sido interpretado por la Corte de San José. Aquí, la idea es interpretar el derecho nacional teniendo en cuenta, en particular, el principio pro-homine mencionado en el artículo 29 de la Convención. Si tal operación interpretativa no es posible, entonces el control de convencionalidad reviste una intensidad más importante que será puesta en obra en función de las posibilidades con que cuenten los jueces en cada sistema. Dos opciones son entonces consideradas: la primera consiste en inaplicar la norma nacional contraria dentro de un caso dado; la segunda, más radical, consiste en declarar su invalidez en el ordenamiento jurídico con efecto erga omnes. Tal demostración de los límites del juez nacional con respecto al derecho convencional no tiene su equivalente como tal en el ámbito del sistema de la Convención Europea ${ }^{113}$.

Este enfoque procesal acerca del papel del juez nacional en la buena ejecución de las sentencias de la Corte ha recibido una acogida extremamente variada en América Latina. Hay países que han tomado muy en serio esta exigencia procesal, aceptando de contera las consecuencias de tal control. México es ejemplar en este sentido. El sistema de justicia militar mexicano fue condenado en el caso Radilla Pacheco, una condena confirmada, por otra parte, en varias ocasiones ${ }^{114}$. El constituyente decidió, después de un gran debate nacional, reformar la Constitución mexicana para tomar en cuenta de mejor manera el derecho internacional de los derechos humanos ${ }^{15}$; esto fue seguido por la Corte Suprema, que aceptó sin pestañear la autoridad de cosa interpretada las sentencias de la Corte Intera-

\footnotetext{
113 Para un excelente estado del arte sobre la cuestión, reenviamos a JIMENA QUESADA, Luis (2010), pp. 285317. Además, para una mirada desde el "interior" de la Corte, véase el artículo del antiguo juez polaco de la Corte Europea: GARLICHKI, Lech (2011), pp. 271-280.

114 Corte IDH, 30 de agosto de 2010, Excepciones Preliminares, Fondo y Reparaciones, Fernández Ortega y otros (“Campo Algodonero") vs. México, Serie C No 215, párr. 234; Corte IDH, 31 de agosto de 2010, Excepciones Preliminares, Fondo y Reparaciones, Rosendo Cantú y otras vs. México, Serie C No 216, párr. 219; Corte IDH, 26 de noviembre de 2010, Excepciones Preliminares, Fondo y Reparaciones, Cabrera García y Montiel Flores vs. México, Serie C No 220, párr. 225.

115 Reforma Constitucional en el Diario Oficial de 10 de junio de 2011 que modifica el artículo 1.
} 
mericana $^{116}$. En contraste, la teoría del control de convencionalidad ha causado muchas más dificultades en otros países. Las jurisdicciones supremas brasileña ${ }^{117} \mathrm{y}$ venezolana ${ }^{118}$, por ejemplo, no lo han tenido en cuenta en absoluto, peor aún, se han rebelado abiertamente contra sus consecuencias en la escala nacional ${ }^{119}$. Aquí puede observarse la amplitud de las dificultades que conlleva aceptar un estándar "procedimental" de consecuencias sustanciales mayores, sobre todo en países marcados, el primero por la importancia otorgada a la primacía de su ordenamiento jurídico $^{120}$, el otro por una política institucional marcada tanto de populismo como de valorización de la soberanía nacional ${ }^{121}$. En otros países, a pesar de la apertura hacia el derecho internacional de los derechos humanos y hacia la jurisprudencia interamericana de los tribunales nacionales, algunas interpretaciones erróneas de las sentencias de la Corte IDH pueden lesionar la exigencia de una correcta ejecución. La interpretación errónea de la Corte Suprema del Uruguay

116 Corte Suprema de México, 14 de julio de 2011, expediente 912/2010.

117 En Brasil, el caso Araguaia (Corte IDH, 24 de noviembre de 2010, Excepciones Preliminares, Fondo y Reparaciones, Gomes Lund y otros ("Guerrilha do Araguaia") vs. Brasil, Serie C No 219) fue el origen de la reacción "soberana" del Tribunal Federal Supremo. Hay que decir que su actitud (de rechazo a ejercer un control de convencionalidad y a declarar la inconstitucionalidad de la ley de amnistía) fue "estigmatizada" por la Corte IDH en el párrafo 177. Este pasaje causó un gran revuelo en Brasil, al punto de atraer la ira del Presidente del Tribunal Supremo, quien hizo saber a través de la prensa que el más alto tribunal de Brasil no estaba vinculado por las sentencias de la Corte Interamericana: v., Declaración del Presidente del Supremo Tribunal Federal, Cezar Peluso, quien afirmó que: "A eficacia (da decisao da Corte Interamericana de Direitos Humanos) se da no campo da convencionalidade. Nao revoga, nao anula e nao cassa a decisao do Supremo" (http://amazonstreet.wordpress.com/ 2011/04/12/lei-da-anistiae-decisao-da-corte-interamericana/).

118 En una sentencia de 26 de septiembre de 2011, la Sala Constitucional del Tribunal Supremo de Justicia de Venezuela declaró desprovista de fuerza ejecutoria en Venezuela una sentencia de la Corte Interamericana emitida el 1 de septiembre de 2011 (López Mendoza, Serie C No 233). Cabe señalar que ante cada condena de Venezuela, el gobierno de Hugo Chávez amenazó con denunciar la Convención y con no reconocer la jurisdicción de la Corte. Sus miembros fueron sistemáticamente estigmatizados por su falta de independencia y de integridad. En otras palabras, se trató de una política de "deslegitimación" constante de los mecanismos institucionales del sistema interamericano, que fue implementada por las autoridades de Caracas, antes de su retirada oficial de la Convención Americana el 6 de septiembre de 2012.

119 Ruiz-Chiriboga, Oswaldo (2010), pp. 200-219. Para un análisis muy crítico de la forma como los tribunales nacionales ejecutan (de manera defectuosa) o no ejecutan las sentencias condenatorias y con lo cual toman o no en cuenta el "estándar" interamericano, ver Huneeus, Alexandra (2013), pp. 112-139.

120 De Carvalho Ramos, A. (2009), pp. 805-850; De Oliveira Mazzuoli, O. (2010), pp. 175-199.

121 Brewer Carias, Alan R. (2009), pp. 89-136; Ayala Corao, Carlos (2001); del mismo autor (2009), pp. 391-395; (2009 b), 125 pp. 
de la sentencia Gelman puso en peligro en este país la correcta ejecución en todo el aparato judicial ${ }^{122}$.

\section{B. Las consecuencias politicas}

El sistema interamericano ha vivido, a intervalos regulares, fases de turbulencia donde las presiones políticas se ponen en marcha para debilitar su influencia. En la actualidad, la desconfianza de los Estados está en su cenit. Si dicha desconfianza culminó con la denuncia de Venezuela de la Convención Americana, el 6 de septiembre de 2012 -una denuncia que tuvo efecto un año más tarde, el 6 de septiembre de $2013^{123}$-, ella continúa haciéndose evidente en las ofensivas de otros países contra la Comisión Interamericana. La necesidad urgente de reformar el organismo fue invocada en nombre de su necesaria consolidación; en realidad, asistimos a una estrategia de debilitamiento. Fueron Brasil, Perú y Venezuela -liderados por Ecuador- quienes lanzaron en 2011 la idea del proceso de reforma de la Comisión Interamericana. Las propuestas buscaban trasladar su sede de Washington a Buenos Aires, restringir sus poderes en materia de medidas cautelares, reducir la importancia de sus informes estatales (country reports) y, por último pero no menos importante, limitar poderes de los relatores especiales (creados por la propia Comisión), es decir, del relator sobre libertad de expresión. Por el momento, la ofensiva no ha tenido éxito, pues se intentó aprovechar la renovación de los miembros de la Comisión para la elección de un candidato "a sueldo" (presentado por Perú), para socavar la institución desde dentro. La elección de 7 de junio de 2013 en el marco de la Asamblea General de la OEA en Guayaquil (Ecuador) permitió impedir lo peor. Si esta estrategia da resultados un día, toda la estructura del sistema interamericano de protección de derechos humanos podría sufrir las consecuencias. En opinión de los especialistas, se trata de la crisis más grave que ha vivido el sistema desde su

122 El Poder Ejecutivo había tomado en cuenta los aprendizajes de la sentencia Gelman. Con el fin de suprimir la ley de amnistía, adoptó el Decreto 323 de 30 junio de 2011 y la Ley No 18.831 de 27 octubre de 2011. Sin embargo, el problema surgió con la jurisprudencia del Tribunal Supremo de Justicia quien, en la sentencia de 22 de febrero de 2013, "pervirtió" completamente el sentido de la sentencia Gelman. Véase, Corte IDH, 20 de marzo de 2013, Resolución, Control de la ejecución de las sentencias, Gelman vs. Uruguay. El juez Ferrer Mac Gregor agregó una importante opinión separada concordante.

123 Hasta ahora, sólo Trinidad y Tobago había denunciado el sistema americano. Perú bajo la dictadura de Fujimori, también lo denunció, pero la llegada al poder de un régimen democrático puso fin a este proceso. 
creación ${ }^{124}$. No obstante, la Comisión ha sido, desde el principio, la columna vertebral del sistema y continúa realizando un trabajo excepcional. Después de haber puesto bajo presión a las dictaduras ${ }^{125}$, ella controla actualmente las faltas de las democracias latinoamericanas jóvenes y frágiles y, por ello, suscita su desconfianza ${ }^{126}$.

En este contexto, la Corte no está exenta de ataques de todo tipo por parte de esos mismos Estados cuyo grado de madurez democrática es, después de todo, muy débil. En un ambiente similar, no es absurdo preguntarse si los métodos de interpretación de la Corte de San José producen estos signos de desconfianza que toman la apariencia de ofensivas de desestabilización. En realidad no son los métodos, más bien son los resultados puntuales los que "irritan" a ciertos gobiernos. Aunque democráticos, ellos son todavía bastante frágiles, marcados por un "presidencialismo" a ultranza (típico de la historia latinoamericana) y proclives a flirtear con el populismo. Así, cuando la Corte acepta que un opositor político sea candidato a las elecciones en Venezuela señalando la violación del derecho a las elecciones (artículo 23.2) ${ }^{127}$ o cuando demuestra la parcialidad de las autoridades judiciales del país del difunto Hugo Chávez; cuando recuerda la importancia del respeto de los derechos de los periodistas (ejerciendo en el seno de un periódico de oposición) en el Ecuador o, incluso, cuando ordena la suspensión de la construcción de una represa con el fin de proteger los territorios de las comunidades

124 Remitimos al número especial de Human Rights Brief (Winter 2013) y al artículo de CASSEL, Doug (2013), pp. 1-10.

125 La Comisión Interamericana de Derechos Humanos fue creada en 1959 -a través de una resolución aprobada en la quinta reunión de los Ministros de Relaciones Exteriores de los Estados Miembros de la OEA reunidos en Santiago de Chile. La resolución de Santiago señaló expresamente el deterioro de la situación política en varios países de América Latina -como República Dominicana, con la dictadura de Rafael Trujilloy, en consecuencia, indicó la necesidad de remediar la violación de los derechos humanos en el continente. El 25 de mayo de 1960 se aprobó su Estatuto y se instaló en sus oficinas de Washington. Entonces pudo iniciar su actividad, que se centró principalmente -antes del establecimiento y el funcionamiento efectivo de la Corte Interamericana de Derechos Humanos a comienzos de la década de 1980- en las visitas in loco y en la publicación correspondiente de los informes nacionales (country reports), FARER, Tom J. (1997), pp. 510-515. Ver también la parte de este artículo consagrado al contexto político.

126 Es sorprendente constatar que la Convención Americana fue preparada y ratificada por Estados que estaban, en la época, gobernados por regímenes "autoritarios". Hoy en día, son los Estados gobernados por partidos de izquierda quienes son los más virulentos contra el sistema interamericano de derechos humanos en su conjunto. La historia es decididamente paradójica.

127 Corte IDH, 1 de septiembre de 2011, Excepciones Preliminares, Fondo y Reparaciones, López Mendoza vs. Venezuela, Serie C No 233. 
indígenas de Brasil, en el marco de sus competencias en materia de "medidas provisionales", ella toca directamente cuestiones que se encuentran en el centro de las agendas presidenciales. Está claro que no son los métodos de interpretación utilizados para llegar a las conclusiones de violaciones los que son contestados por los gobiernos, sino más bien sus resultados concretos en casos específicos.

Dicho esto, una jurisprudencia audaz que juega con los límites de la interpretación evolutiva puede rápidamente exasperar y engendrar múltiples resistencias. La desconfianza política de los gobiernos puede de hecho aumentar si una interpretación evolutiva modifica significativamente el enfoque de un derecho o si se ataca a los fundamentos culturales y políticos de una joven sociedad democrática en busca de equilibrio ${ }^{128}$.

Si el caso Atala Riffo causó gran escándalo en el territorio latinoamericano por haber condenado a Chile por discriminación de la demandante por motivos de orientación sexual ${ }^{129}$, no parece haber causado resistencias particulares en términos de su ejecución. En efecto, la legislación chilena no fue cuestionada in se, sino la jurisprudencia de la Corte Suprema de Chile que, in casu, había revertido las decisiones de los jueces quienes habían dado la razón a la demandante. En este contexto, los órganos ejecutivos y parlamentarios fueron ejemplares, al decidir mejorar el cuerpo legislativo mediante la preparación y la adopción de una nueva ley (No 20.609 de 24 de julio de 2012) que establece una selección de medidas contra la discriminación ${ }^{130}$. La reacción de la Corte Suprema estuvo lejos de ser tan conciliadora pues, al mismo tiempo, el país de Pablo Neruda atravesaba por numerosos debates donde todos los componentes de la sociedad se expresaban: organizaciones no gubernamentales, representantes de las minorías sexuales y de la Iglesia Católica, e igualmente miembros del Poder Judicial, del cuerpo académico y los medios de comunicación en su conjunto. Las discusiones dejaron ver las profundas divisiones en la evolución de las costumbres de un país que -aunque es liberal desde el punto de vista económico- es profundamente conservador en asuntos de sociedad $^{131}$. ¿Las reacciones negativas de franjas enteras de la sociedad

128 Es particularmente el caso cuando se trata de reconciliarse, es decir, de conseguir que una sociedad fracturada por un pasado doloroso sea capaz de sanar esta herida colectiva.

129 Corte IDH, 24 de febrero de 2012, Fondo y Reparaciones, Atala Riffo e hijas vs. Chile, Serie C No 239.

130 Ivanschitz Boudeger, B. (2013), pp. 275-332.

131 Lo que es seguro es que si las instancias legislativas y ejecutivas adoptaron una actitud respetuosa de cara al sistema interamericano, la Corte Suprema -criticada directamente en este asunto- sin duda tuvo dificultades para aceptar el control de la Corte Interamericana. Javier Couso explica con brío este punto 
chilena son fragmentos de un distanciamiento frente al mecanismo regional de protección de los derechos humanos? ${ }^{132}$ Del mismo modo, ¿el caso de la Fecundación in vitro (que condenó a Costa Rica por haber prohibido las técnicas de reproducción in vitro) ${ }^{133}$ no va a engendrar en algunos círculos políticos y entre ciertos componentes de las sociedades latinoamericanas (todas ellas atravesadas por el poder de la Iglesia Católica) una "irritación” que podría convertirse en desconfianza o resistencia? La cuestión no es baladí en un contexto sociopolítico marcado por una recrudescencia de corrientes de ideas a favor de la prohibición del aborto.

Una desconfianza menos política y mediática, pero igualmente peligrosa podría ser adicionada: la de las jurisdicciones internas. En los dos casos mencionados (como en el resto del contencioso), las decisiones de las jurisdicciones internas y particularmente de las supremas se han visto socavadas por dichas condenas emblemáticas. ¿Cómo mantener entonces la confianza de las jurisdicciones a nivel nacional? El asunto es eminentemente sensible y se refleja sobre el tema, más preciso, de la ejecución de las sentencias de la Corte Interamericana. Sabemos que los Estados ejecutan, por regla general, las sentencias en los aspectos financieros mediante la indemnización de las víctimas y/o sus familiares y a través de la implementación de reparaciones simbólicas como las excusas públicas. En contraste, los demás tipos de reparaciones (apertura o profundización de las investigaciones judiciales, cambios legislativos ${ }^{134}$, reformas judiciales, etc.), son mucho menos ejecutados ${ }^{135}$. ¿La interpretación evolutiva es un obstáculo más

de vista en su estudio, mostrando la estructura altamente jerárquica del Poder Judicial chileno. La Corte Suprema dispone, en efecto, de poderes imponentes.

132 Corte IDH, 28 de noviembre de 2012, Excepciones Preliminares, Fondo y Reparaciones, Artavia Murillo y otros (Fecundación in vitro) vs. Costa Rica, Serie C No 257.

133 Hay excepciones, por supuesto, y el caso de La última tentación de Cristo fue uno de los primeros en ser completamente "ejecutado" gracias a una reforma de la Constitución chilena. Más recientemente, fue Argentina quien ejecutó enteramente la sentencia Kimel de 2 de mayo de 2008 sobre la libertad de expresión: el país cambió su legislación interna sobre el delito de difamación (Corte IDH, 5 de mayo de 2013, Resolución sobre la aplicación de la sentencia Kimel vs. Argentina).

134 Para mayores detalles, véase Corso Sosa, E.; Carmona Tinoco, J.U.; SaAvedri Alessandri, P. (coord.), (2013), p. 463.

135 Entre las obras más importantes en lengua francesa: MASTOR, W., Les opinions séparées des juges constitutionnels, Aix Marseille, Economica-PUAM, 2005, p. 361; RIVIÈRE, F., Les opinions séparées des juges à la Cour européenne des droits de l'homme, Bruxelles, Bruylant, 2004, p. 464; LECUYER, Y. "Le secret des délibérés, les opinions séparées et la transparence”, Revue trimestrielle des droits de l'homme, 2004, pp. 197 223; MarguénAUd, J-P, “L’opinion séparée du juge siégeant à la Cour européenne des droits de l'homme au 
para la ejecución de las decisiones? Si añadimos a esto la "obligación" subyacente de la teoría del control de convencionalidad para los tribunales nacionales (v. supra), las cosas son particularmente complejas y potencialmente propicias a reacciones "epidérmicas".

\section{Las consecuencias institucionales}

¿La interpretación evolutiva podrá perdurar al mismo ritmo y con la misma audacia pasada? ¿No va a engendrar resistencias en el seno mismo de la Corte produciendo disidencias fuertes que podrían, in fine, socavar su legitimidad interna y su legitimidad vis-à-vis la opinión pública latinoamericana? El contencioso reciente no está ajeno a estas preguntas.

Este no es el lugar para hacer un inventario interminable de inconvenientes y/o ventajas de la posibilidad de emitir votos particulares que pueden tomar la forma de disidencias imponentes. Los trabajos no faltan en estas temáticas ${ }^{136}$. Seguramente, en esta posibilidad de expresión (individual y/o colectiva) hay un compromiso a la vez de independencia, transparencia y de mejora de la calidad de la motivación, por no hablar de la puesta en marcha de un mecanismo judicial democrático ${ }^{137}$. No es menos cierto que la presencia de estas posiciones deja ver el estado de las correlaciones de fuerza dentro de una jurisdicción (sea nacional o internacional). Existe, por lo tanto, para el ciudadano en general -es decir, para el "receptor" de las decisiones judiciales- una manera de descubrir rápida y claramente lo que está en juego, en la medida de las disputatio que han atravesado la deliberación. Más allá de los ciudadanos - muy a menudo federados en el continente latinoamericano a partir de un entramado de organizaciones no gubernamentales- las instancias políticas permanecerán particularmente atentas a la actualización de las fracturas internas. En el contexto latinoamericano actual

titre de l'Etat défendeur", Mélanges en l'honneur de Jean-Paul Costa, La conscience des droits, Dalloz, 2011, pp. 421-430; Rousseau, D., "Pour les opinions dissidentes Mélanges Gélard Patrice, Paris, Montchrestien, 1999, pp. 323-328; Wildhaber, L., "Opinions dissidentes” et concordantes de juges individuels à la Cour européenne des droits de l'homme”, Mélanges en l'honneur de Nicolas Valticos. Droit et justice, Paris, Pedone, 1999, pp. 529-538.

136 Entre las obras más importantes en lengua francesa: MASTOR, Wanda (2005), p. 361; RIVIERE, Florence (2004), p. 464; Marguenaud, Jean-Pierre (2011), pp. 421-430; Rousseau, Dominique (1999), pp. 323-328; WILDHABER, Luzius (1999), pp. 529-538.

137 Estos diferentes puntos de vista fueron adecuadamente puestos en evidencia por SCHAHMANECHE, Aurélia (2012), p. 868; véase, igualmente, Bruck, Véronique, LARChe, Marion (2012), pp. 65-83. Las mismas conclusiones son aplicables a la Corte Interamericana. 
-caracterizado por ataques políticos particularmente virulentos contra la Comisión y la Corte- esto no es trivial. El "juego" político de ciertos gobiernos no debe ser subestimado: éste consiste en instrumentalizar todo lo que pueda serlo, para deteriorar la imagen del sistema de garantía de los derechos humanos como tal, pero igualmente la imagen de ciertos jueces, a veces tomados como partidarios ad nominem. Podemos desde ahora imaginar perfectamente que algunos Estados utilicen como parte de su política jurídica exterior las disidencias de los jueces, sobre todo cuando critican posiciones marcadas por el progresismo evolutivo de la Corte, para continuar debilitando las garantías regionales.

Si los votos razonados siempre han acompañado el curso de los litigios interamericanos ${ }^{138}-\mathrm{y}$ esto desde sus comienzos ${ }^{139}$-, si algunas de las opiniones disidentes no han pasado desapercibidas por los temas abordados y por el "tono" empleado ${ }^{140}$, no es menos cierto también que, desde 2010 , ha habido un aumento en la frecuencia y, especialmente, un cambio de orientación en su contenido. Si en la historia del litigio interamericano la mayoría de votos han sido "concurrentes razonados" -buscando especialmente aclarar a veces con una gran cantidad de argumentos técnicos la decisión tomada por unanimidad, los votos recientes han tomado de repente un giro crítico más sistemático. Dicho de otro modo, mientras la mayor parte de los votos disidentes anteriores se alzaban contra la

138 Y esto, de conformidad con el artículo 66.2 de la Convención y el artículo 24.3 del Estatuto de la Corte. Conviene señalar que las opiniones separadas (votos particulares) son igualmente admitidas tanto en el marco de la función consultiva como en el otorgamiento de medidas provisionales.

Aquí remitimos al análisis agudo de E. Voeten quien, utilizando métodos muy precisos de análisis y basado en las opiniones separadas de los jueces del Tribunal Europeo de Derechos Humanos, fue capaz de "clasificarlos", es decir, de organizarlos desde el más "activista" al más "mesurado". Véase Voeten, Erik (2007), pp. 669-701.

139 Fue el juez costarricense R. Piza Escalante quien inauguró la emisión de votos particulares. Esto sucedió durante la primera sentencia de fondo en el asunto Velásquez Rodríguez vs. Honduras (Corte IDH, 29 de julio de 1988, serie C No 4) y, de nuevo, en la interpretación de la cuestión de las reparaciones en el mismo caso (Corte IDH, Interpretación de la Sentencia de Reparaciones, 19 de agosto de 1990, Velásquez Rodríguez vs. Honduras, Serie C No 9). Este juez persistirá en otro de los primeros casos hondureños que marcó la irrupción del contencioso de las desapariciones forzadas en la Corte Interamericana (Corte IDH, Interpretación de la Sentencia de Reparaciones y Costas, 17 de agosto de 1990, Godínez Cruz vs. Honduras, Serie C No 10).

140 Algunos votos particulares de A. Cançado Trindade son significativos en este sentido. Ellos fueron reagrupados en una obra publicada por Porrúa México (en colaboración con la Universidad Iberoamericana): CanÇado Trindade, Antônio (2007), p. 1055. Este juez escribió no menos de 90 votos particulares durante sus dos mandatos consecutivos ( 4 en la función consultiva, 63 en la función contenciosa y 23 en el marco de medidas provisionales). Sobre este impresionante conjunto, sólo 7 de ellas son "disidentes". 
falta de audacia de la Corte, las recientes disidencias se ofenden, a la inversa, en la mayoría de los casos por su "activismo".

Este podría ser el preludio de una nueva fase en la historia del contencioso interamericano, que corresponde al cambio en la composición del órgano jurisdiccional interamericano que se efectuó en el transcurso de 2010. La chilena Cecilia Medina Quiroga y el mexicano Sergio García Ramírez finalizaron sus mandatos y fueron reemplazados por el uruguayo y chileno Pérez Pérez y Vio Grossi, respectivamente. Además, la llegada de dos nuevos jueces el 1 de enero $2013^{141}$ provenientes del universo del derecho constitucional continúa modificando radicalmente la fisonomía interna de la Corte Interamericana. Es importante señalar que la fisura entre activismo y restricción judicial -que sabemos, es un clásico del derecho judicial de la protección internacional ${ }^{142}$ - está cada vez más presente en el litigio interamericano. Si éste se ha caracterizado durante mucho tiempo por un activismo legendario, dotado de creatividad y originalidad, también comienza subrepticiamente a estar marcado, en interne, por rupturas donde la restricción judicial se manifiesta con más frecuencia y de manera más espectacular que antes; a veces incluso el self restraint logra imponerse ${ }^{143}$. Si en esta etapa no es posible y, aun menos, oportuno extraer conclusiones definitivas acerca de este proceso, no es menos importante dilucidarlo con el fin de estar en capacidad de evaluar sus efectos en el corto y mediano plazo.

En el lapso de tres años (enero 2010-agosto 2013), sobre cincuenta y tres decisiones emitidas por la Corte IDH en el marco de su función contenciosa, veinticinco han venido acompañadas de opiniones separadas. El juez chileno Vio Grossi aparece como el "campeón" de esta técnica de expresión judicial, expresándose en catorce oportunidades, siete de ellas con opiniones concordantes y siete de ellas para expresar críticas tanto a la motivación como a la solución adoptada por la mayoría. A modo de comparación, el presidente de la Corte, el peruano García Sayán, se ha expresado en siete ocasiones y ha expresado una

141 Ellos reemplazaron a las dos jueces mujeres, respectivamente, dominicana (R. Abreu Blondet) y jamaiquina (M. May Macaulay).

142 Aquí remitimos al análisis agudo de E. Voeten quien, utilizando métodos muy precisos de análisis y basado en las opiniones separadas de los jueces del Tribunal Europeo de Derechos Humanos, fue capaz de "clasificarlos", es decir, de organizarlos desde el más "activista" al más "mesurado". Véase International Organization (2007), pp. 669-701.

143 Acosta Alvarado, P.A. y Nunes Poblete, M. (dir.) (2012). Véanse igualmente los desarrollos de Rota, M., en la materia (2013), pp. 257-275. 
sola opinión parcialmente disidente; el uruguayo Pérez Pérez ha intervenido, por su parte, cinco veces para emitir no obstante en tres ocasiones votos parcialmente disidentes. En cuanto al juez E. Ferrer Mac-Gregor, si sólo ha emitido cinco opiniones, en un lapso reducido pues él integró la Corte el 1 de enero de 2013, ellas no han pasado inadvertidas. Primero, porque son particularmente sustanciales, largas y sumamente argumentadas desde el ángulo técnico. Además, porque ellas ponen perfectamente en evidencia la corriente progresista, incluso activista, que el juez mexicano encarna; su rol aparece ya de modo central y continuará sin duda encarnándolo. Sus votos concordantes le han permitido en el pasado "teorizar" el control de convencionalidad (caso Cabrera y Montiel Flores); presentar pistas de reflexión particularmente progresistas para integrar de manera más extensiva los derechos económicos y sociales en la jurisdicción de la Corte (caso Suárez Peralta); valorar la importancia de la independencia judicial de los Estados de derecho (caso Tribunal Supremo de Justicia). En cuanto a sus votos disidentes, ellos le dieron la oportunidad de lamentar el examen de proporcionalidad inadecuado, efectuado por los jueces argentinos sobre la libertad de expresión y aceptación de éste por parte de la Corte Interamericana (sentencia de Mémoli) y que, de la misma manera, la Corte Interamericana no haya aprovechado la oportunidad para reconocer la violación del artículo 9 (legalidad y retroactividad) en un caso de destitución masiva de jueces por parte del Parlamento de Ecuador (caso Tribunal Constitucional). Son muchos los signos reveladores de una voluntad de continuar usando los métodos de interpretación evolutiva al servicio de una protección máxima de los derechos humanos.

Frente a ello, existe otra tendencia en el seno de la Corte IDH marcada por un "clasicismo" analítico proclive a la restricción. Esta última corriente está claramente representada por el juez chileno Vio Grossi, quien está "marcando" el curso de la jurisprudencia interamericana por la multiplicación de sus votos particulares. Ellos han abordado temas que van desde la cuestión de la articulación de la competencia de las jurisdicciones nacionales y la Corte Interamericana para calcular las indemnizaciones (sentencia Cepeda Vargas), la calidad de derecho colectivo de las comunidades indígenas como tales (caso Comunidad Indígena Xákmok Kásek) o, incluso, sobre la cuestión de las desapariciones forzadas y las leyes de amnistía (caso Gelman). El lector podrá tomar la medida de su constancia intelectual comparado, por ejemplo, con los tiempos de A. Cançado Trindade quien, ne varietur, defendía sus posiciones iusnaturalistas. En efecto, el juez Vio Grossi manifiesta una constancia similar en la defensa, por su parte, de reglas ortodoxas 
de interpretación en cuanto a la Convención de Viena que constituyen el cursor de su análisis. Esto no quiere decir que se ha alzado sistemáticamente contra las soluciones adoptadas por la mayoría. De hecho, las técnicas de interpretación del "Tratado de los tratados" -en particular el artículo 31.1 de la Convención de Viena- lo han llevado varias veces a defender la solución adoptada por la Corte. Así lo hizo en la cuestión de la noción colectiva de los derechos de las comunidades indígenas (Comunidad Indígena Xákmok Kásek) y en lo relativo al alcance del artículo 23.2 de los derechos políticos (López Mendoza). Sin embargo, el uso de sus reglas de interpretación lo ha conducido esencialmente a oponerse a la mayoría, defendiendo posiciones que, in fine, tendrían como consecuencia optar por alternativas restrictivas. Así, en el caso Barbani Duarte y otros, defendió que el artículo 8.1 no se aplicaba a los hechos del caso, teniendo en cuenta que la Corte, en contradicción frontal con las normas del derecho internacional público, había procedido a una modificación de su contenido cuando la tarea de tal modificación de la Convención pertenece a los Estados y sólo a ellos.

Una de las disidencias más emblemáticas fue la desarrollada en el caso Artavia Murillo (Fecundación in vitro). Ella es manifiestamente importante, en primer lugar, porque es una de las más estudiadas y desarrolladas entre sus disidencias: sus veintidós páginas tienen como objeto "desmontar" uno a uno los aspectos más destacados de la solución de la mayoría y del voto concurrente razonado del presidente García Sayán que, por su parte, se esforzó en reconocer y legitimar la solución de la Corte Interamericana. Ella es igualmente importante porque se trata de una crítica al método de interpretación evolutiva utilizado por la Corte de San José en un asunto de los más delicados, a saber, la cuestión de lo que es la vida y si es posible compararla con otros intereses legítimos en un caso de la sala constitucional de la Corte Suprema de Costa Rica que declaró la inconstitucionalidad de la técnica de la fecundación in vitro. El juez disidente compone el escenario desde el comienzo cuando declara:

"Ciertamente, los comentarios incluidos en este voto disidente se han hecho considerando, no lo que el intérprete desea, sino lo que el Derecho expresa. Igualmente, se ha tenido en cuenta que a la Corte le corresponde interpretar y aplicar la Convención y no asumir la función que le compete a la Comisión Interamericana de Derechos Humanos ni la función normativa, la que le corresponde a los Estados, únicos habilitados para eventualmente modificar la Convención Y, final y especialmente, se ha tenido presente que de lo que se trata es [de] precisar lo que la voluntad de los Estados expresaron en la Convención y acuerdos y práctica posteriores, de suerte de poder exigirles aquello a lo que efectivamente se comprometieron". 
El discurso es el de un internacionalista "clásico" -algunos se atreverían a decir "old fashion"- que se basa en las normas básicas que regulan la expresión de la voluntad de los Estados; en una palabra, de un voluntarista positivista. A partir de esta posición de principio, la disidencia criticó toda una serie de puntos específicos. Primero, la manera como la Corte IDH siguió, de entrada, la lógica de la argumentación de la Comisión Interamericana y de los representantes, quienes pusieron en una balanza los diversos derechos en presencia -el derecho a la vida de un lado (artículo 4) versus los derechos al honor y la dignidad (artículo 11.2), la protección de la familia (artículo 17.2) y la igualdad ante la ley (artículo 24) de otro lado. En este sentido, afirmó que: "Al proceder como ha hecho, la Sentencia no solo sigue la lógica procesal y argumental que legítimamente plantearon la Comisión y los Representantes, muy acorde a sus respectivos intereses y roles procesales, por lo demás, sino que de esa forma en definitiva y en la práctica minimiza o subordina todo lo referente al 'derecho a la vida' ante los otros mencionados derechos". En ningún momento el juez disidente toma en cuenta que la disputa tiene como punto de partida personas que estiman que sus derechos han sido violados y que es precisamente sobre la base de sus reclamaciones que el juez de los derechos humanos debe estatuir. En ningún momento el juez disidente toma en cuenta que la ponderación de intereses es una de las mayores funciones de cualquier tribunal que conoce asuntos relativos a los derechos humanos y que éste debe, como en las cortes constitucionales, juzgar teniendo en cuenta el principio de proporcionalidad. En ningún momento el juez disidente toma en cuenta que la Corte Interamericana no es una Corte de arreglo de controversias judiciales entre los Estados y que el nexus del control se sitúa a nivel del daño sufrido por las víctimas.

El juez chileno no es el único en desafiar el uso y los efectos de la interpretación evolutiva. Los pocos votos separados emitidos por el juez uruguayo permiten considerar que si ciertamente no es tan "ortodoxo" como su contraparte chilena, tampoco es menos "prudente". El caso Atala Riffo es en este sentido un buen ejemplo. El juez Pérez Pérez contestó en su voto parcialmente disidente que la Corte haya decidido la violación del artículo 17.1 que consagra la protección de la familia. Si no contestó como tal la técnica de interpretación evolutiva que debe basarse en la existencia de un "consenso entre los Estados Parte" -consenso que considera verdadero con respecto a la no discriminación en materia de orientación sexual (párr. 20 de su voto)- no consideró, por lo tanto, que este consenso esté presente con respecto a la noción de la familia (artículo 21). Así, estimó que al declarar la violación del artículo 17.1, la Corte habría 
implícitamente desarrollado una interpretación particular de la familia. Y en el párrafo 23 de su opinión afirmó que este es un dominio donde es necesario reconocer un "margen nacional de apreciación" a los Estados. Si añadimos a estos elementos el contenido de su opinión concurrente en el caso Suárez Peralta-donde insiste en que el derecho a la salud no es justiciable en el marco convencional americano-, las grandes líneas de las divergencias entre los jueces pueden dibujarse con facilidad.

No es absurdo preguntarse, como resultado de este rápido inventario de las oposiciones recientes en el seno de la Corte -y de algunas resistencias (judiciales y en ocasiones sociales) en el seno de los Estados Parte-, si la teoría del margen nacional de apreciación tomará fuerza un día en el sistema interamericano. Por ahora, aunque podemos encontrar algunos rastros en la jurisprudencia, ellos son tenues y son más bien el producto de la estrategia de defensa de los Estados demandados en la ocasión. Y por esta razón, los jueces han considerado hasta ahora que la doctrina del margen nacional de apreciación es "peligrosa" en el marco del contexto interamericano. Esto no impide que los casos de Atala Riffo o la Fecundación in vitro permitan pensar que el tema está "en sintonía con los tiempos”... En cualquier caso, ya está en sintonía con el mundo académico latinoamericano.

Si los métodos de interpretación de la Corte Interamericana han estado y siguen estando globalmente marcados por una apertura a fuentes externas, revelan un cosmopolitismo normativo característico de la esencia del derecho contemporáneo; lo cierto es que los cambios en la composición que han afectado recientemente a la Corte Interamericana dejan ver divisiones sin precedentes en el seno de la Corte. El positivismo voluntarista tiene a partir de ahora un representante de talla: la corriente opuesta igualmente. Las confrontaciones y las oposiciones ya se han hecho presentes y no hay ninguna razón para que se atenúen y disminuyan. En sí, no hay nada específico en ello. El Tribunal Europeo de Derechos Humanos ha atravesado por los mismos tipos de corrientes y de oposiciones internas. No debería, sin embargo, permitir que ellas sean utilizadas -por no hablar de instrumentalizadas- por una opinión pública hostil y especialmente por gobiernos demasiado prontos en querer debilitar el sistema interamericano de derechos humanos. 


\section{ANEXos}

1. Lista de los casos contenciosos que han dado lugar a votos particulares (Enero 2010-Agosto 2013)

2010

C-213, Cepeda Vargas (Corte IDH, Excepciones Preliminares, Fondo, Reparaciones y Costas, 26 de mayo de 2010, Cepeda Vargas vs. Colombia, Serie C No 213).

Cuatro votos particulares, dos concordantes (García Sayán, Vio Grossi) y dos parcialmente disidentes (Ventura Robles, Pérez Pérez).

C-214, Comunidad Indígena Xákmok Kásek (Corte IDH, Fondo y Reparaciones, 24 de agosto de 2010, Comunidad Indígena Xákmok Kásek vs. Paraguay, Serie C No 214).

Dos votos particulares, uno concurrente (Vio Grossi) y uno disidente (juez ad hoc Fogel Pedrozo).

C-215, Fernández Ortega y otros (Corte IDH, Excepciones Preliminares, Fondo, Reparaciones y Costas, 30 de agosto de 2010, Fernández Ortega y otros vs. México, Serie C No 215).

Un voto particular del juez ad hoc Espinosa.

C-216, Rosendo Cantú y otra (Corte IDH, Excepciones Preliminares, Fondo, Reparaciones y Costas, 31 de agosto de 2010, Rosendo Cantú y otra vs. México, Serie C No 216).

Dos votos particulares (juez ad hoc Espinosa y juez R. Abreu Blondet).

C-219, Gomes Lund y otros (Corte IDH, Excepciones Preliminares, Fondo, Reparaciones y Costas, 24 de noviembre de 2010, Gomes Lund y otros (Guerrilha do Araguaia) vs. Brasil, 24 de noviembre de 2010, Serie C No 219).

Un voto particular concurrente (juez ad hoc brasileño Figueiredo Caldas).

C-220, Cabrera García y Montiel Flores (Corte IDH, Excepciones Preliminares, Fondo, Reparaciones y Costas, 26 de noviembre de 2010, Cabrera García y Montiel Flores vs. México, Serie C No 220).

Un voto particular concurrente (juez ad hoc mexicano E. Ferrer Mac-Gregor).

2011

C-221, Gelman (Corte IDH, Excepciones Preliminares, Fondo, Reparaciones y Costas, 24 de febrero de 2011, Gelman vs. Uruguay, Serie C No 221). 
Un voto particular concurrente (juez Vio Grossi).

C-222, Salvador Chiriboga (Corte IDH, Reparaciones, 3 de marzo de 2011,

Salvador Chiriboga vs. Ecuador, Serie C No 222).

Seis votos particulares parcialmente disidentes (García Sayán, Medina Quiroga

y juez ad hoc Rodríguez Pinzón, García Ramírez, Franco, Macaulay).

C-229, Torres Millacura y otros (Corte IDH, Fondo y Reparaciones, 26 de agosto de 2011, Torres Millacura y otros vs. Argentina, Serie C No 229).

Un voto particular concurrente (juez Vio Grossi).

C-233, López Mendoza (Corte IDH, Fondo y Reparaciones, 1 de septiembre de 2011, López Mendoza vs. Venezuela, Serie C No 233).

Dos votos particulares concurrentes (jueces García Sayán y Vio Grossi).

C-234, Barbani Duarte y otros (Corte IDH, Fondo y Reparaciones, 13 de octubre de 2011, Barbani Duarte y otros vs. Uruguay, Serie C No 234).

Cuatro votos particulares, tres concurrentes (García Sayán, Macaulay, Abreu Blondet) y uno disidente (Vio Grossi).

C-237, Familia Barrios (Corte IDH, Fondo y Reparaciones, 24 de noviembre de 2011, Familia Barrios vs. Venezuela Serie C No 237).

Un voto particular concurrente (juez Vio Grossi).

\section{2}

C-239, Atala Riffo e hijas (Corte IDH, Fondo y Reparaciones, 24 de febrero de 2012, Atala Riffo e hijas vs. Chile, Serie C No 239).

Un voto parcialmente disidente (Pérez Pérez).

C-241, Pacheco Teruel y otros (Corte IDH, Fondo y Reparaciones, 24 de abril de 2012, Pacheco Teruel y otros vs. Honduras, Serie C No 241).

Un voto disidente (Vio Grossi).

C-244, Díaz Peña (Corte IDH, Excepciones Preliminares, Fondo y Reparaciones,

Díaz Peña vs. Venezuela, 26 de junio de 2012, Serie C No 244).

Un voto disidente (Vio Grossi).

C-246, Furlán y familiares (Corte IDH, Excepciones Preliminares, Fondo y Re-

paraciones y Costas, Furlán y familiares vs. Argentina, 31 de agosto de 2012, Serie C No 246).

Un voto concurrente (juez May Macaulay). 
C-249, Uzcátegui y otros (Corte IDH, Fondo y Reparaciones, Uzcátegui y otros vs. Venezuela, 26 de junio de 2012, Serie C No 249).

Un voto llamado "concurrente", pero en realidad disidente (Vio Grossi).

C-252, Masacre de El Mozote y lugares aledaños (Corte IDH, Fondo y Reparaciones, Masacre de El Mozote y lugares aledaños vs. El Salvador, 25 de octubre de 2012, Serie C No 252).

Dos votos concurrentes (García Sayán, Vio Grossi).

C-255, Mohamed (Corte IDH, Excepciones Preliminares, Fondo y Reparaciones,

Mohamed vs. Argentina, 23 de noviembre de 2012, Serie C No 255).

Un voto parcialmente disidente (Pérez Pérez).

C-257, Artavia Murillo (Fecundación in vitro) (Corte IDH, Excepciones Preliminares, Fondo y Reparaciones, Artavia Murillo (Fecundación in vitro) vs. Costa Rica, 28 de noviembre de 2012, Serie C No 257).

Dos votos particulares, uno concurrente (García Sayán) y uno disidente (Vio Grossi).

C-258, García y familiares (Corte IDH, Excepciones Preliminares, Fondo y Reparaciones, García y familiares vs. Guatemala, 29 de noviembre de 2012, Serie C No 258).

Un voto llamado "concurrente", pero en realidad disidente (Vio Grossi).

2013

C-261, Suárez Peralta (Corte IDH, Excepciones Preliminares, Fondo y Reparaciones, Suárez Peralta vs. Ecuador, 21 de mayo de 2013, Serie C No 261).

Dos votos concurrentes (E. Ferrer Mac-Gregor, Pérez Pérez).

C-265, Mémoli (Corte IDH, Excepciones Preliminares, Fondo y Reparaciones, Mémoli vs. Argentina, 22 de agosto de 2013, Serie C No 265).

Tres votos particulares, dos concurrentes (García Sayán, Pérez Pérez) y un voto parcialmente disidente común (E. Ferrer Mac-Gregor, Ventura Robles y Vio Grossi).

C-266, Corte Suprema de Justicia (Quintana Coello y otros) (Corte IDH, Excepciones Preliminares, Fondo y Reparaciones, Corte Suprema de Justicia (Quintana Coello y otros) vs. Ecuador, 23 de agosto de 2013, Serie C No 266). Un voto concurrente (E. Ferrer Mac-Gregor).

C-268, Corte Constitucional (Camba Campos y otros) (Corte IDH, Excepciones Preliminares, Fondo y Reparaciones, Corte Constitucional (Camba Campos y otros) vs. Ecuador, 28 de agosto de 2013, Serie C No 268).

Un voto parcialmente disidente (E. Ferrer Mac-Gregor). 
2. Tabla de los votos particulares de los jueces de la Corte Interamericana (Enero 2010-Agosto 2013)

\begin{tabular}{|c|c|c|c|c|c|c|c|c|c|c|c|c|}
\hline Caso & R.AB** & R.FC & L.AF & E.FMG & M.MM** & C.MQ* & S.GR* & D.GS & M.VR. & E.VG & A.PP & $\begin{array}{c}\text { Juez } \\
\text { ad hoc }\end{array}$ \\
\hline C-213 & & & & & & & & VC & VPD & VC & VPD & \\
\hline C-214 & & & & & & & & & & VC & & VPC \\
\hline C-215 & & & & & & & & & & & & VC \\
\hline C-216 & VC & & & & & & & & & & & VC \\
\hline C-219 & & $\begin{array}{l}\text { VC } \\
\text { (J. ad hoc }\end{array}$ & & & & & & & & & & \\
\hline C-220 & & & & $\begin{array}{c}\text { VC } \\
\text { (J. } \\
\text { ad hoc) }\end{array}$ & & & & & & & & \\
\hline C-221 & & & & & & & & & & VC & & \\
\hline $\begin{array}{l}\text { C-222 } \\
\text { (ré.) }\end{array}$ & & & VPD & & VPD & VPD & VPD & VPD & & & & VPD \\
\hline C-229 & & & & & & & & & & VC & & \\
\hline C-233 & & & & & & & & VC & & VC & & \\
\hline C-234 & VC & & & & VC & & & VC & & OD & & \\
\hline C-237 & & & & & & & & & & VC & & \\
\hline C-239 & & & & & & & & & & & VPD & \\
\hline C-241 & & & & & & & & & & VD & & \\
\hline C-244 & & & & & & & & & & VD & & \\
\hline C-246 & & & & & VC & & & & & & & \\
\hline C-249 & & & & & & & & & & VD & & \\
\hline C-252 & & & & & & & & VC & & VC & & \\
\hline C-255 & & & & & & & & & & VPD & \\
\hline C-257 & & & & & & & & VC & & VD & & \\
\hline C-258 & & & & & & & & & & VD & & \\
\hline C-261 & & & & VC & & & & & & & VC & \\
\hline C-265 & & & & VPD & & & & VC & VPD & VPD & VC & \\
\hline C-266 & & & & VC & & & & & & & & \\
\hline C-268 & & & & VPD & & & & & & & & \\
\hline
\end{tabular}

VC: Voto Concurrente / VD: Voto Disidente / VPD: Voto Parcialmente Disidente.

* La presencia de jueces C. Medina Quiroga y S. García Ramírez en esta tabla (a pesar de que terminaron su mandato en 2009) se explica por el hecho de que tenían que decidir en reparaciones acerca de un caso, la sentencia C-222 Salvador Chiriboga (del cual participaron durante su mandato en las etapas de excepciones preliminares y fondo).

** Rhady Abreu Blondet (R.AB) y Margaret May Macaulay (M. MM) también están presentes en la lista, pues se mantuvieron en su cargo hasta finales de 2012.

R.AB Rhady Abreu Blondet (República Dominicana), R.FC Roberto Figueiredo Caldas (Brasil), LA.F Leonardo A. Franco (Argentina), E.FMG Eduardo Ferrer Mac-Gregor (México), M. MM Margaret May Macaulay (Jamaica), C.MQ Cecilia Medina Quiroga (Chile), S.GR, Sergio García Ramírez (México), D.GS Diego García Sayán, M.VR Manuel Ventura Robles (Costa Rica), E.VG Eduardo Vio Grossi (Chile), A.PP Alberto Pérez Pérez (Uruguay). 


\section{BIBLIOGRAFIA CITADA}

Abello-Galvis, R. (2012): "La jerarquía normativa en la Corte Interamericana de Derechos Humanos: evolución jurisprudencial del ius cogens 1993-2012", en Revista del Instituto Brasileiro de Dereitos Humanos, Año 12, Vol. 12 (№ 12).

Acosta Alvarado, P. A.; Nunes Poblete, M. (2012) (dir.): El Margen de Apreciación en el Sistema Interamericano de Derechos Humanos: Proyecciones Regionales y Nacionales, IIJ, UNAM, México.

Arnold, R.; Martinez Estay, J.-I.; Zúniga Urbina, F. (2012): "El principio de proporcionalidad en la jurisprudencia del Tribunal Constitucional”, en Estudios Constitucionales, Año 10.

Ayala Corao, Carlos (2001): La Libertad de Expresión Amenazada. Sentencia 1.013, San José/Caracas.

(2009 a): "Comentarios sobre la sentencia de la Sala Constitucional del Tribunal Supremo de Justicia de Venezuela (No 1939) del 18 de diciembre de 2008", en Estudios Constitucionales, Vol. No 7 (No 1).

(2009 b): La inejecución de las sentencias internacionales en la jurisprudencia constitucional de Venezuela 1999-2009 (Caracas, Fundación García Pelayo).

(2012): Del Diálogo jurisprudencial al control de convencionalidad, Caracas, Editorial Jurídica Venezolana.

Brewer Carias, Alan R. (2009): "La interrelación entre los tribunales constitucionales en América Latina y la Corte Interamericana de Derechos Humanos y la cuestión de la inejecutabilidad de sus decisiones en Venezuela”, en Anuario Iberoamericano de Justicia Constitucional (No 13).

BRUCK, Véronique; Larche, Marion (2012), "La motivation des décisions de la Cour européenne", Annuaire International de Justice Constitutionnelle AIJC, XXVIII.

Burgorgue-Larsen, Laurence (2010): "Le destin judiciaire strasbourgeois de la Charte des droits fondamentaux de l'Union européenne. Vices et vertus du cosmopolitisme normatif", Chemins d'Europe, Mélanges en l'honneur de Jean Paul Jacqué, París, Dalloz.

(2011): "Présentation", Le droit international de la personne humaine, A. Cançado Trindade, París, Pedone (Col. "Doctrines").

(2012 a): "La erradicación de la impunidad: análisis de la jurisprudencia de la Corte Interamericana", El derecho en movimiento. En 
Homenaje a Elena Highton, A. Dreyzin de Klor (dir.), C. Harrington (coord.) (Buenos Aires, Rubinzal-Culzoni Editores).

(2012 b): "Interpreting the European Convention: What can the African Human Rights System learn from the case law of the European Court of Human Rights on the Interpretation of the European Convention?", Int. Am. \& Eur. Hum. Rts. J. / Rev. Int. Am. \& Eur. D.H., Vol. 5.

(2014): "Nothing is perfect. Libres propos sur la méthodologie interprétative de la Cour européenne", Mélanges en l'honneur de Jean-François Flauss (París, Pedone).

Burgorgue-Larsen, Laurence; Úbeda De Torres, Amaya (2011 a): The InterAmerican Court of Human Rights. Case Law and Commentary (Oxford, OUP). (2011 b): "War in the jurisprudence of the Inter-American Court of Human Rights", Human Rights Quaterly, Vol. 33.

Cançado Trindade, Antônio (1983): The Application of the Rule of Exhaustion of Local Remedies in International Law, Cambridge, Cambridge University Press. (2007): Derecho Internacional de los Derechos Humanos. Esencia y Trascendencia. (Votos en la Corte Interamericana de Derechos Humanos, 1991-2006).

(2010): International Law for Humankind - Towards a New Jus Gentium, Leiden/The Hague, Nijhoff/The Hague Academy of International Law (Monograph Series n. 6).

Carozza G., Paolo (1998): "Uses and Misuses of comparative law in International Human Rights: some reflections on the jurisprudence of the European Court of Human Rights", Notre Dame Law Review, Vol. 73.

(2003): "From Conquest to Constitutions: Retrieving a Latin American Tradition of the Idea of Human Rights", Human Rights Quaterly, Vol. 25.

Cassel, Doug (2013): "Regional Human Rights Regimes and State Push Back: The Case of the Inter-American Human Rights System", Human Rights Law Journal, Vol. 33.

Castilla, Karlos (2011): "El control de convencionalidad: un nuevo debate en México a partir de la sentencia del caso Radilla Pacheco", en Anuario Mexicano de Derecho Constitucional, Vol. XI, 2011.

ClériCO, Laura (2012): "Hacia la reconstrucción de un modelo integrado de proporcionalidad a la luz de la jurisprudencia de la Corte Interamericana de 
Derechos Humanos", Internacionalización del derecho constitucional, Constitucionalización del derecho internacional, G. Capaldo, J. Sieckmann, L. Clérico (dir.) (Eudeba, Fundación Humboldt, Buenos Aires).

Corso Sosa, Edgar; Carmona Tinoco, J.U.; SaAcedri Alessandri, Pablo (coord.) (2013): Impacto de las sentencias de la Corte Interamericana de Derechos Humanos (Tirant lo Blanch, México D.F.).

Couso, Javier (2012): "Reacciones institucionales y sociales al 'fallo Atala' en Chile, Igualdad y Orientacion sexual. El caso Atala de la Corte Interamericana de Derechos Humanos y su potencial", A. Von Bogdandy, F. Piovesan, M. Morales Antonazzi (coord.), México (Ed. Porrúa. IMDPC), 2012 (Biblioteca Porrúa de Derecho Procesal Constitucional).

De Carvalho Ramos, A. (2009): "O Dialogo das Cortes: O Supremo Tribunal Federal e a Corte Interamericana de Direitos Humanos", Quartier Latin Do Brasil.

De Oliveira Mazzuoli, O. (2010): "The Inter-American Human Rights protection system: structure, functionning and effectiveness in Brazilian Law", Revista Interamericana y Europea de Derechos Humanos.

EstuPINAN-SiLva, Rosmerlin (2014): "La vulnérabilité dans la jurisprudence de la Cour interaméricaine des droits de l'homme: esquisse d'une typologie", $\mathrm{La}$ vulnérabilité saisie par les juges en Europe, L. Burgorgue-Larsen (dir.), (París, Pedone). (Col. "Cahiers européens").

FARER, Tom J. (1997): "The Rise of the Inter-American Human Rights Regime: No Longer a Unicorn, Not Yet an Ox", Human Rights Quaterly.

Ferrer Mac-Gregor, Eduardo (2010): "El control difuso de convencionalidad en el Estado constitucional”, H. Fix-Zamudio, D. Valades (coord.), Formación y perspectiva del Estado Mexicano, (México D.F., El Colegio Nacional-UNAM).

Ferrer Mac-Gregor, Eduardo (dir.) (2013a): Panorámica del derecho procesal constitucional y convencional (México, IIJ-UNAM).

Ferrer Mac-Gregor, Eduardo; Herrera García, A. (dir.) (2013 b): Diálogo jurisprudencial en Derechos humanos entre Tribunales Constitucionales y Cortes Internacionales, In memoriam Jorge Carpizo (México, Tirant lo Blanch).

FitzPatricK, J. (2004): "States of Emergency in the Inter-American Human Rights System", The Inter-American System of Human Rights, D.J. Harris, S. Linvingston (eds.) (Oxford, Oxford University Press).

García Morelos, G. (2010): El control judicial difuso de convencionalidad de los derechos humanos por los tribunales ordinarios en México (México D.F., Ubijus). 
García Ramírez, Sergio; Islas De González Mariscal, O. y Ojeda Velásquez, Islas (2013): Código Penal para el Distrito Federal a diez años de vigencia. XIII Jornadas sobre Justicia Penal "Rafael Marqueza Pinero" (México D.F., Porrúa-UNAM). García Ramírez, Sergio; Morales SÁnchez, Julieta (2012); La reforma constitucional sobre derechos humanos (2009-2011), 2ª ed. (México D.F., Porrúa-UNAM).

GARLICHKI, Lech (2011): "Contrôle de constitutionnalité et contrôle de Convenciónnalité", La conscience des droits. Mélanges en l'honneur de Jean-Paul Costa (París, Dalloz).

Goldman, Robert K. (2009): "History and Action: the Inter-American Human Rights System and the Role of the Inter-American Commission on Human Rights", Human Rights Quaterly, 31.

Góngora Mera, Manuel (2011): Inter-American Judicial constitutionalism. On the Constitutional Rank of Human Rights Treaties in Latin America through National and Inter-American Adjudication, IIDH.

GonZÁLEZ, Felipe (2009): "The Experience of the Inter-American Human Rights System", VUWLR, 40 (2009).

Gros Espiell, Héctor (1989): "La Convention américaine et la Convention européenne des droits de l'homme - Analyse comparative", RCADI, 1989, T. VI (No 218). (San José, Corte IDH).

(1994): "Los métodos de interpretación utilizados por la Corte Interamericana de los Derechos Humanos en su jurisprudencia contenciosa”, en R. Nieto Navia (dir.), La Corte y el Sistema Interamericano de Derechos Humanos, San José, Corte IDH.

Grossmann, Claudio (2007): "The Velásquez Rodríguez Case: The Development of the Inter-American Human Rights System”, International Law Stories, Foundation Press.

HuneEus, Alexandra (2013): "Rejecting the Inter-American Court: Judicialization, National Courts and Regional Human Rights", Cultures of Legality, Judicialization and Political Activism in Latin America, J. Couso, A. Huneeus, R. Sieder (eds.) (Cambridge, Cambridge University Press).

IVANSCHITZ BOUDEGER, B. (2013): “Un estudio sobre el cumplimiento y ejecución de las sentencias de la Corte Interamericana de Derechos Humanos por el Estado de Chile", Estudios Constitucionales, Año 11 (No 1), 2013, pp. 275-332.

Jimena QuesadA, Luis (2010): "Control de constitucionalidad y control de convencionalidad. Hacia la formación de un derecho constitucional europeo”, 
Congreso de la Asociación española de derecho constitucional (Valencia, Tirant lo Blanch).

LIXINSKI, L. (2010): "Treaty Interpretation by the Inter-American Court of $\mathrm{Hu}-$ man Rights: Expansionism at the Service of the Unity of International Law", European Journal of International Law.

Marguenaud, Jean-Pierre (2011): "L'opinion séparée du juge siégeant à la Cour européenne des droits de l'homme au titre de l'Etat défendeur", Mélanges en l'honneur de Jean-Paul Costa, La conscience des droits (París, Dalloz).

Martin-Chenut, Kathia (2008): "La condition juridique de l'enfant dans la jurisprudence interaméricaine des droits de l'homme", Revue des Sciences critiques.

Martin, Claudia (2007): "Catching Up with the Past: Recent Decisions of the Inter-American Court of Human Rights Addressing Gross Human Rights Violations Perpetred During the 1970-1980s", Human Rights Law Review.

MASTOR, Wanda (2005): Les opinions séparées des juges constitutionnels (Aix Marseille, Económica-PUAM).

Medina Quiroga, Cecilia (1988): The Battle of Human Rights, Gross Systematic violations and the Inter-American System, Martinus Nijhoff Publishers, 1988. (2005): La Convención americana: vida, integridad personal, libertad personal, debido proceso y recurso judicial (Universidad de Chile, Facultad de Derecho, Centro de Derechos Humanos).

Neuman, Gerald L. (2008): "Import, Export and Regional Consent in the InterAmerican Court of Human Rights", European Journal of International Law, Vol. 19.

PARRA Vera, Óscar (2012): "La jurisprudencia de la Corte Interamericana respecto a la lucha contra la impunidad: algunos avances y debates", Revista Jurídica de la Universidad de Palermo, Año 13 (No 1).

PASQUAluCCI, J. Mo. (1995): "Sonia Picado, First Woman Judge on the Inter-American Court of Human Rights", Human Rights Quaterly, Vol. 17 (No 4).

Rey Cantor, Ernesto (2008): Control de convencionalidad de las leyes y derechos humanos (México, Porrúa).

RIVIERE, Florence (2004): Les opinions séparées des juges à la Cour européenne des droits de l'homme (Bruxelles, Bruylant), p. 464.

RotA, Marie (2013): L'interprétation des Conventions américaine et européenne des droits de l'homme. Analyse comparée de la jurisprudence des deux Cours de protection des droits de l'homme, Tesis, Universidad de Caen - Baja Normandía, p. 701 (Directores de tesis, L. Burgorgue-Larsen y M.J. Redor). 
Rousseau, Dominique (1999): "Pour les opinions disidentes" Mélanges Patrice Gélard (París, Montchrestien).

Ruiz-Chiriboga, Oswaldo (2010): “The Convencionality control: examples of (un)sucessful experiences in Latin America”, Revista Interamericana y Europea de Derechos Humanos, Vol. 3 (No 1-2).

(2012): "The Independence of the Inter-American Judge", The Law and Practice of International Courts and Tribunals (Martinus Nijhoff/Brill).

Ruprimmy, Rodrigo; SafFon, M.P. (2008): "Usos y abusos de la Justicia Transicional en Colombia", Anuario de Derechos Humanos (Chile).

SAGÜÉs, Néstor Pedro (2010 a): "Obligaciones internacionales y control de convencionalidad”, Estudios Constitucionales, Santiago de Chile, Año 8 (No 1).

(2010 b): "Dificultades operativas del control de convencionalidad en el sistema interamericano” (La Ley, Buenos Aires).

(2011): "El control de convencionalidad en el sistema interamericano y sus anticipos en el ámbito de los derechos económico-sociales. Concordancias y diferencias con el sistema europeo", Construcción y papel de los derechos fundamentales. Hacia un ius constitutionale comune, A. Von Bogdandy, H. Fix-Fierro, M. Morales Antoniazzi, E. Ferrer Mac-Gregor (coord.), Construcción y papel de los derechos sociales fundamentales, IIJ-Max Planck (IIDC, UNAM, México).

Schahmaneche, Aurélia (2012): La motivation des décisions de la Cour européenne des droits de l'homme, Tesis, Universidad de Montepellier I, 2012, 868 pp. (Director de Tesis, F. Sudre).

Société Francaise De Droit International (SFDI) (2003): La juridictionnalisation du droit international (París, Pedone).

Special Issue, Human Rights Brief, "The Future of the Inter-American System of Human Rights", Vol. 20, Issue 2, Winter 2013.

Thiele, B. (2003): "Litigating against forced evictions under the American Convention on Human Rights", Netherlands Quarterly of Human Rights, Vol. 21/3.

Voeten, Erik (2007): "The Politics of International Judicial Appointments: Evidence from the European Court of Human Rights", International Organization, Vol. 61 (No 4).

WildHABER, Luzius (1999): "Opinions dissidentes et concordantes de juges individuels à la Cour européenne des droits de l'homme", Mélanges en l'honneur de Nicolas Valticos. Droit et justice (París, Pedone). 


\section{NORMAS JURÍDICAS CITADAS}

\section{Normas universales}

Principios para la Protección de los Enfermos Mentales y el Mejoramiento de la Salud Mental (Doc. NU/A/46/49,1991).

Protocolo de Minnesota (Doc. NU/E/ST/CSDHA/12, 1991).

CDESC, Observación General No 12, 12 de mayo de 1999, E/C.12/1999/5.

CDESC, Observación General No 13, 8 de diciembre de 1999, E/C.12/1999/10.

CDESC, Observación General No 15, $29^{\circ}$ período de sesiones de 2002, HRI/ GEN/1/Rev. 7 en 117.

CDESC, Observación General No 21, 21 de diciembre de 2009, E/C.12/GC/21.

\section{Normas interamericanas}

Declaración Americana de los Derechos y Deberes del Hombre, 2 de mayo de 1948.

Convención Americana de los Derechos Humanos, conocida igualmente bajo el nombre de "Pacto de San José", del 22 de noviembre de 1969.

Convención Interamericana contra la Tortura y Otros Tratos o Penas Crueles, Inhumanos o Degradantes, del 8 de diciembre de 1985.

Protocolo de San Salvador sobre Derechos Económicos y Sociales, del 17 de noviembre de 1988.

Convención Interamericana sobre Desapariciones Forzadas, del 9 de junio de 1994.

Convención Interamericana para Prevenir, Sancionar y Erradicar la Violencia contra la Mujer, del 9 de junio de 1994.

\section{Normas nacionales}

\section{Chile}

Ley No 20.609, de 24 de julio de 2012.

\section{Uruguay}

Decreto Ejecutivo No 24029, de 3 de febrero de 1995.

Decreto 323, de 30 junio de 2011, Ley No 18.831, de 27 de octubre de 2011. 
JURISPRUDENCIA CITADA

Jurisprudencia internacional

Corte Interamericana de Derechos Humanos

Opiniones consultivas

Corte IDH, "Otros tratados". Objeto de la función consultiva de la Corte (artículo 64 de la Convención Americana), AC-1/82, Opinión Consultiva de 24 de septiembre de 1982, Serie A, No 1.

Corte IDH, 30 de enero de 1987, El habeas corpus bajo suspensión de garantías, Serie A No 8.

Corte IDH, 6 de octubre de 1987, Las garantías judiciales en estados de emergencia, Serie A No 9.

Corte IDH, 28 de agosto de 2002, Condición jurídica y derechos humanos del niño, Serie A No 17.

Corte IDH, 17 de septiembre de 2003, Condición jurídica y derechos de los trabajadores migrantes indocumentados, Serie A No 18.

\section{Sentencias}

Corte IDH, Excepciones Preliminares, 26 de junio de 1987, Velásquez Rodríguez vs. Honduras, Serie C No 1.

Corte IDH, Fondo, 29 de julio de 1988, Velásquez Rodríguez vs. Honduras, Serie C No 4.

Corte IDH, 10 de septiembre de 1993, Reparaciones, Aloeboetoe y otros c. Suriname, Serie C No 15.

Corte IDH, 19 de noviembre de 1999, Fondo, Villagrán Morales y otros ("Niños de la Calle") vs. Guatemala, Serie C No 63.

Corte IDH, 4 de febrero de 2000, Excepciones Preliminares, Las Palmeras vs. Colombia, Serie C No 67.

Corte IDH, 16 de agosto de 2000, Fondo, Durandy Ugarte vs. Perú, Serie C No 68.

Corte IDH, 18 de agosto de 2000, Fondo, Cantoral Benavides vs. Perú, Serie C No 69.

Corte IDH, 25 de noviembre de 2000, Bámaca Velásquez vs. Guatemala, Serie C No 70. 
Corte IDH, 31 de agosto de 2001, Fondo y Reparaciones, Comunidad Mayagna (Sumo) Awas Tigni vs. Nicaragua, Serie C No 79.

Corte IDH, 14 de marzo de 2001, Fondo, Barrios Altos vs. Perú, Serie C No 75.

Corte IDH, 3 de septiembre de 2001, Interpretación, Barrios Altos vs. Perú, Serie C No 83.

Corte IDH, 27 de noviembre de 2003, Fondo y Reparaciones, Maritza Urrutia vs. Guatemala, Serie C No 103.

Corte IDH, 7 de junio de 2003, Fondo, Humberto Sánchez vs. Honduras, Serie C No 99.

Corte IDH, 8 de julio de 2004, Hermanos Gómez Paquiyauri vs. Perú, Serie C No 110 .

Corte IDH, 23 de noviembre de 2004, Excepciones Preliminares, Hermanas Serrano Cruz vs. El Salvador, Serie C No 118.

Corte IDH, 1 de marzo de 2005, Fondo y Reparaciones, Hermanas Serrano Cruz vs. El Salvador, Serie C No 120.

Corte IDH, 7 de marzo de 2005, Fondo y Reparaciones, Masacre de Mapiripán vs. Colombia, Serie C No 122.

Corte IDH, 11 de marzo de 2005, Fondo y Reparaciones, Caesar vs. Trinidady Tobago, Serie C No 123.

Corte IDH, 23 de junio de 2005, Yatama vs. Nicaragua, Serie C No 127.

Corte IDH, 1 de febrero de 2006, Fondo y Reparaciones, López Álvarez vs. Honduras, Serie C No 141.

Corte IDH, 29 de marzo de 2006, Fondo y Reparaciones, Comunidad Indígena Sawhoyamaxa vs. Paraguay, Serie C No 146.

Corte IDH, 4 de julio de 2006, Fondo y Reparaciones, Ximenes Lopes vs. Brasil, Serie C No 149.

Corte IDH, 22 de septiembre de 2006, Fondo y Reparaciones, Goiburu vs. Paraguay, Serie C No 153.

Corte IDH, 26 de septiembre de 2006, Fondo y Reparaciones, Almonacid Arellano y otros vs. Chile, Serie C No 154.

Corte IDH, 25 de noviembre de 2006, Fondo y Reparaciones, Prisión Miguel Castro Castro vs. Perú, Serie C No 160.

Corte IDH, 29 de noviembre de 2006, Fondo y Reparaciones, La Cantuta vs. Perú, Serie C No 162. 
Corte IDH, 11 de mayo de 2007, Fondo y Reparaciones, Bueno Alves vs. Argentina, Serie C No 164.

Corte IDH, 30 de octubre de 2008, Excepciones Preliminares, Fondo y Reparaciones, Bayarri vs. Argentina, Serie C No 187.

Corte IDH, 1 de julio de 2009, Excepciones Preliminares, Fondo y Reparaciones, Acevedo Buendía y otros (Cesantes y jubilados de la Contraloría) vs. Perú, Serie C No 198.

Corte IDH, 19 de septiembre de 2009, Fondo y Reparaciones, Claude Reyes vs. Chile, Serie C No 151.

Corte IDH, 24 de septiembre de 2009, Excepciones Preliminares, Fondo y Reparaciones, Dacosta Cadogan vs. Barbados, Serie C No 204.

Corte IDH, 3 de abril de 2009, Fondo y Reparaciones, Kawás Fernández vs. Honduras, Serie C No 196.

Corte IDH, 24 de noviembre de 2009, Excepciones Preliminares, Fondo y Reparaciones, Masacre de Las Dos Erres vs. Guatemala, Serie C No 211.

Corte IDH, 26 de mayo de 2010, Excepciones Preliminares, Fondo y Reparaciones, Cepeda Vargas vs. Colombia, Serie C No 213.

Corte IIDH, 24 de agosto de 2010, Fondo y Reparaciones, Comunidad Indígena Xákmok Kásek vs. Paraguay, Serie C No 214.

Corte IDH, 30 de agosto de 2010, Excepciones Preliminares, Fondo y Reparaciones, Fernández Ortega y otros ("Campo Algodonero") vs. México, Serie C No 215.

Corte IDH, 31 de agosto de 2010, Excepciones Preliminares, Fondo y Reparaciones, Rosendo Cantú y otras vs. México, Serie C No 216.

Corte IDH, 26 de noviembre de 2010, Excepciones Preliminares, Fondo y Reparaciones, Cabrera Garcia y Montiel Flores vs. México, Serie C No 220.

Corte IDH, 24 de noviembre de 2010, Excepciones Preliminares, Fondo y Reparaciones, Gomes Lund y otros (Guerrilha do Araguaia) vs. Brasil, Serie C No 219.

Corte IDH, 26 de noviembre de 2010, Excepciones Preliminares, Fondo y Reparaciones, Cabrera García y Montiel Flores vs. México, Serie C No 220.

Corte IDH, 24 de febrero de 2011, Fondo y Reparaciones, Gelman vs. Uruguay, Serie C No 221.

Corte IDH, 1 de septiembre de 2011, Excepciones Preliminares, Fondo y Reparaciones, López Mendoza vs. Venezuela, Serie C No 233.

Corte IDH, 24 de febrero de 2012, Fondo y Reparaciones, Atala Riffo e hijas vs. Chile, Serie C No 239. 
Corte IDH, 27 de junio de 2012, Fondo y Reparaciones, Pueblo Indígena Kichwa de Sarayaku vs. Ecuador, Serie C No 245.

Corte IDH, 28 de noviembre de 2012, Excepciones Preliminares, Fondo y Reparaciones, Artavia Murillo y otros (Fecundación in vitro) vs. Costa Rica, Serie C No 257.

Corte IDH, 30 de noviembre de 2012, Excepciones Preliminares, Fondo y Reparaciones, Masacre de Santo Domingo vs. Colombia, Serie C No 259.

Corte IDH, 20 de marzo de 2013, Resolución, Control de la ejecución de las sentencias, Gelman vs. Uruguay.

Corte IDH, 5 de mayo de 2013, Resolución sobre la aplicación de la sentencia Kimel vs. Argentina.

Corte IDH, 21 de mayo de 2013, Excepciones Preliminares, Fondo, Reparaciones y Costas, Suárez Peralta vs. Ecuador, Serie C No 261.

Corte IDH, 22 de agosto de 2013, Excepciones Preliminares, Fondo, Reparaciones y Costas, Mémoli vs. Argentina, Serie C No 265.

Corte IDH, 23 de agosto de 2013, Excepciones Preliminares, Fondo y Reparaciones, Corte Suprema de Justicia (Quintana Coello y otros) vs. Ecuador, Serie C No 266.

Corte IDH, 28 de agosto de 2013, Excepciones Preliminares, Fondo y Reparaciones, Tribunal Constitucional (Camba Campos y otros) vs. Ecuador, Serie C No 268.

\section{Tribunal Internacional de Justicia}

TIJ, 20 de abril de 2010, Usines de pâtes à papier sur le fleuve Uruguay (Argentine c. Uruguay), C.I.J, Recueil, 2010.

\section{Tribunal Europeo de los Derechos Humanos}

TEDH, 21 de noviembre de 2001, Al-Adsani vs. Reino Unido.

\section{Tribunal Penal Internacional para la ex Yugoslavia}

TPIY, 10 de diciembre de 1998, Prosecutor vs. Furundzij.

\section{Jurisprudencia nacional}

\section{Costa Rica}

Corte Suprema de Justicia, Sala Constitucional, 15 de marzo de 2000. 
Uruguay

Tribunal Supremo de Justicia, 22 de febrero de 2013.

México

Corte Suprema de México, 14 de julio de 2011, expediente 912/2010. 